\title{
Akademisyenlerin Açık Erişim ve Kurumsal Akademik Arşiv Konusunda Bilgi ve Farkındalık Düzeylerinin Belirlenmesi: Bartın Üniversitesi Uygulama Örneği*
}

\author{
Determining the Level of Knowledge and Awareness of Academicians on Open \\ Access and Institutional Repositories: An Example of Bartın University
}

\author{
Burcu Umut Zan**, Ahmet Altay ${ }^{* * *}$, Huriye Çolaklar**** ve Nuri Taşkın***** \\ $\ddot{O}_{z}$
}

Kurumsal açık arşiv sistemleri, üniversiteler ve araştırma merkezleri tarafindan üretilen entelektüel çalışmaların elektronik ortamda arşivlendiği ve herkesin serbestçe erişilebildiğ $i$ platformlardır. Üniversitelerin, kurumsal açık arşiv sistemlerinin, sürekliliği için akademisyenler tarafindan güncelliğinin să̆lanması gerekmektedir. Bu sürekliliğin sağlanmasında açık erişim ve kurumsal akademik arşiv konusunda öğretim elemanlarının bilgi ve farkındalık düzeylerinin yüksek olmasının önemli olduğu düşünülmektedir. Bu çalışmada, Bartın Üniversitesi akademisyenlerinin açık erişim ve kurumsal akademik arşiv konusundaki bilgi ve farkındalık düzeylerini yükseltmek amacıyla bir eğitim gerçekleştirilmiş ve akademisyenlerin ĕgitim öncesi ve sonrasında bu konudaki düşüncelerinde yaşanan değişimin incelenmesi amaçlanmıştır. Bu kapsamda nicel araştırma yöntemleri kullanılmış ve tek örneklem ön test son test deseni kullanılmıştır. Verilerin analizinde SPSS (Statistical Package for Social Sciences) 22.0 paket programından yararlanılmıştır. Çalışmanın sonucunda, akademisyenlerin açık erişim ve kurumsal açık arşivlerin etkin ve etkili kullanımı

\footnotetext{
${ }^{*}$ Bu çalışmanın, meslek yüksekokulları ile ilgili kısmının ön test verileri '8. International Vocational Schools Symposium, June 11-13, 2019, Sinop-Turkey' sempozyumunda sunulan 'Bartın Üniversitesi Meslek Yüksekokullarında Görev Yapan Öğretim Elemanlarının Açık Erişim ve Kurumsal Arşiv Konusundaki Bilgi ve Farkındalıklarını Belirlemeye Yönelik Bir Araştırma' başlıklı bildiride kullanılmıştır.

The pre-test data of the part of this study related to vocational schools were used in the paper titled "A research to determine the knowledge and awareness of the faculty members of Bartin University vocational schools on open access and institutional repositories" presented at the 8th International Vocational Schools Symposium, June 11-13, 2019, Sinop-Turkey.

** Doç. Dr., Bartın Üniversitesi Bilgi ve Belge Yönetimi Bölümü, E-posta: bumut@ bartin.edu.tr

Assoc. Prof. Dr., Bartin University Department of Information and Document Management, Bartın/Turkey, Email:bumut@bartin.edu.tr

${ }^{* * *}$ Dr. Öğr. Üyesi, Bartın Üniversitesi Bilgi ve Belge Yönetimi Bölümü, E-posta: aaltay@ bartin.edu.tr Assist. Prof. Dr., Bartin University Department of Information and Document Management, Bartın/Turkey, Email: aaltay@bartin.edu.tr

**** Dr. Öğr. Üyesi, Bartın Üniversitesi Bilgi ve Belge Yönetimi Bölümü, E-posta: hcolaklar@bartin.edu.tr Assist. Prof. Dr., Bartin University Department of Information and Document Management, Bartın/Turkey, Email:hcolaklar@bartin.edu.tr

***** Araş. Gör., Bartın Üniversitesi Bilgi ve Belge Yönetimi Bölümü, E-posta: ntaskin@bartin.edu.tr Research Assistant, Bartin University Department of Information and Document Management, Bartin/Turkey, Email: ntaskin@bartin.edu.tr
} 
Akademisyenlerin Açık Erişim ve Kurumsal Akademik Arşiv Konusunda Bilgi ve Farkındalık Düzeylerinin Belirlenmesi: Bartın Üniversitesi Uygulama Örneği

Determining the Level of Knowledge and Awareness of Academicians on Open Access and Institutional Repositories: An Example of Bartin University

konusunda ĕgitimlere gereksinim duydukları belirlenmiştir. Ayrıca verilen eğitim sonrasında akademisyenlerin açık erişim ve kurumsal akademik arşivler konusundaki bilgi ve farkındalıklarında istatistiksel olarak anlamlı (pozitif) değişim gözlendiği sonucuna varılmuştır.

Anahtar Sözcükler: Açık erişim; kurumsal akademik arşivler; kurumsal açık arşiv; akademisyen; dijital dönüşüm; Bartın Üniversitesi.

\begin{abstract}
Institutional open repository systems are platforms where intellectual works which, produced by universities and research centers are archived electronically and freely accessible to everyone. Institutional repository systems are platforms where intellectual studies produced by universities and research centers are archived electronically and freely accessible to everyone. For the continuity of the institutional repository systems of universities, it is necessary to be updated by academicians. It is thought that high level of knowledge and awareness of academic staff about open access and institutional academic archive is important in ensuring this continuity. In this study, a training was carried out in order to increase the knowledge and awareness of Bartin University academicians on open access and institutional academic archives, and it was aimed to examine the changes in the opinions of the academicians before and after the training. In this context, quantitative research methods were used and a single sample pre-test post-test design was used. SPSS (Statistical Package for Social Sciences) 22.0 package program was used to analyze the data. As a result of the study, it was determined that academicians needed training on open access and effective and effective use of institutional repositories. In addition, it was concluded that a statistically significant positive change was observed in the knowledge and awareness of academicians about open access and institutional academic archives after the training provided.
\end{abstract}

Keywords: Open access; institutional academic archives; institutional repositories; digital transformation; academician; Bartın University.

\title{
Giriş
}

Ülkemizde son zamanlarda sayıları hızla artan üniversitelerin birçoğu misyon ve vizyonunu belirlerken araştırma geliştirme çalışmalarına ve bilimsel bilgi birikimine vurgu yapmaktadır. Akademisyenlerin yaptıkları bilimsel çalışmaların beklenen faydaya ulaşması için yazarların yayınlarını telif hakları ve bilimsel etik kurallarını göz önünde bulundurarak açık erişim ve kurumsal açık arşivlere yüklemesi önerilmektedir. Üniversiteler eğitim veren, bilimsel araştırmalar yapan, bilgi üreten, hem bilim dünyasının hem de iş dünyasının gereksinim duyduğu entelektüel sermayeyi yetiştiren önemli bilim ve araştırma kurumlarıdır (Ennals, 2003, s. 92). Bu kurumlarda üretilen bilimsel bilginin gerek ulusal gerekse uluslararası alanda daha geniş kitlelere ulaşabilmesinde açı erişim ve kurumsal akademik arşivlerin önemi büyüktür. Bugün Türkiye'de ve dünyada bazı üniversitelerin kurumsal açık arşiv uygulamalarını kurum politikalarına dâhil ettiği ve bunu bir kurum kültürü haline dönüştürdüğü görülmektedir. Kurumsal açık arşiv sistemlerinin amaç ve hedeflerine 
ulaşabilmesi için akademisyenlerin, ürettikleri bilimsel yayınları kendi üniversitelerinin kurumsal akademik arşivlerine yüklemesi gerekmektedir. $\mathrm{Bu}$ işlemlerin kolaylıkla gerçekleştirilebilmesi ve sürekliliği, akademisyenlerin açık erişim ve kurumsal akademik arşivlerle ilgili bilgi ve farkındalık düzeylerinin yeterliliğine bağlıdır. Ancak Türkiye'de yükseköğretim kurumlarındaki akademisyenler tarafından açık erişim ve kurumsal akademik arşivlerin genel itibariyle -birkaç üniversite dışında- etkin bir şekilde kullanılmaması mevcut durumun henüz istenilen düzeyde olmadığının bir göstergesidir (Alaca, Büyükçolpan ve Kanık, 2019, s. 3-4).

Çalışmada; Bartın Üniversitesinde görev yapan akademisyenlerin açık erişim ve kurumsal akademik arşiv konusundaki farkındalıkları ele alınmıştır. Bu bağlamda, açık erişim ve kurumsal akademik arşiv konusunda akademisyenlere bir eğitim verilmiş, eğitim öncesi ve sonrasında katılımcılara verilen anketler aracılığıyla akademisyenlerin açık erişim ve kurumsal akademik arşivler konusunda bilgilerindeki değişim incelenmiştir. Bu kapsamda çalışmanın ilk basamağında açık erişim ve kurumsal akademik arşivlerin akademisyenlere sağladığ 1 kolaylık ve firsatlar kavramsal çerçevede ele alınmıştır. Daha sonra dünyada ve Türkiye'de bu konuda atılan adımlar kronolojik olarak aktarılmıştır. Bartın Üniversitesi Açık Erişim ve Kurumsal Akademik Arşivinin mevcut durumu ortaya konulduktan sonra üniversitenin akademisyenlerinin kurumsal akademik arşive yaklaşımları ile açık erişim ve kurumsal açık arşivler konusunda bilgi ve farkındalık durumları analiz edilmiştir.

\section{Açık Erişim ve Kurumsal Açık Arşivler: Kavramsal Çerçeve Açık Erişim ve Kurumsal Açık Arşivler}

Türkiye'de açık erişim ve kurumsal açık arşivler konusunda yapılan çalışmalara bakıldığında; üç kavramın yoğun olarak kullanıldığ 1 dikkat çekmektedir: "Kurumsal arşiv", "kurumsal açık arşiv" ve "kurumsal akademik arşiv". Çalışmada kurumlarda işleyiş ve süreçler sonucunda oluşan bilgi ve belgelerin sistematik ve bilimsel bir metotla saklandığı/depolandığı ve korunduğu ve koruma ve saklama odaklı birimler olan kurumsal arşivler (institutional archive) ile karıştırılmaması amacıyla kurumsal açık arşiv (institutional repository) ve kurumsal akademik arşiv kavramlarının kullanılması tercih edilmiştir. Burada kısaca kurumsal açık arşivler ile kurumsal akademik arşivler arasındaki ilişkiye değinmek yararlı olacaktır. Kurumsal açık arşivler bağlı oldukları kurumun entelektüel çıktılarını sistematik ve bilimsel yöntemlerle dijital ortamda bir araya getiren ve erişime sunan bir alanı ifade etmektedir. Kurumsal akademik arşivler ise kurumsal açık arşivlerin bir alt birimi olarak değerlendirilebilir. Bu arşivler akademik kurumlardaki akademik faaliyetler sonucunda ortaya çıkan bilgiyi sistematik ve bilimsel yöntemlerle dijital ortamda bir araya getiren, koruyan, erişime odaklı sistemlerdir. Özellikle uygulama alanında iki kavram birbirinin yerine kullanılsa da; her kurumsal akademik arşiv kurumsal açık arşivdir, ancak her kurumsal açık arşiv kurumsal akademik arşiv değildir.

Kurumsal açık arşivler, kurumların entelektüel birikimini dijital ortamda bir araya getiren, koruyan, saklayan ve dağıtımını sağlayan hizmetler bütünü (Çelik, Gürdal, Keten, Türkfidanı ve Kutlutürk, 2013) olarak tanımlanır. Temel amacı ise kurumda üretilen kitap, tez, makale, bildiri ve rapor gibi akademik yayınların tümünü uluslararası standartlara uygun biçimde elektronik ortamda arşivleyerek telif haklarına uygun bir biçimde açık erişime sunmaktır (Çelik ve Çelik, 2019, s. 91). 
Akademisyenlerin Açık Erişim ve Kurumsal Akademik Arşiv Konusunda Bilgi ve Farkındalık Düzeylerinin Belirlenmesi: Bartın Üniversitesi Uygulama Örneği

Determining the Level of Knowledge and Awareness of Academicians on Open Access and Institutional Repositories: An Example of Bartın University

Kurumsal açık arşivler, özellikle üniversiteler gibi bilimsel kuruluşlar için büyük önem taşımaktadır. Bu noktada kurumsal açık arşivlerin avantajlarını şöyle sıralayabiliriz; bilimsel ve akademik iletişimde erişimi kolaylaştırır, bilim insanlarının inisiyatifi elinde bulundurmalarını sağlar, yayıncılık alanında rekabet ve işbirliği ortamının yaratılmasına imkân tanır, üniversitelere ve kütüphanelere finansal açıdan rahatlık ve tasarruf sağlar, üniversitelerde gerçekleştirilmekte olan bilimsel faaliyetlerin fark edilebilirliğini, kalitesini, değerini ve statüsünü yükseltir, üniversitedeki akademisyen ve öğrencilere, akademik gelişimlerini destekleyen içerik ve çalışmalarını paylaşacak bir platform sunar, disiplinler arası çalışmaları teşvik ederek yeni araştırmalar için ilham ve temel teşkil eder (Afzali, 2009, s. 26; Köse ve Küçük, 2010, s. 264; Eroğlu, 2013, s. 5; Alaca, Büyükçolpan ve Kanık, 2019, s. 10-11). Tüm bu avantajlarının yanı sıra telif hakları konusunda yaşanan sorunlar, ilke, standart ve işleyişle ilgili yasal çerçevenin oluşmaması, teknolojik altyapı ile ilgili sıkıntılar, dizinleme sorunları gibi faktörlerde kurumsal açık arşivlerin dezavantajları olarak kabul edilebilir (Akın, 2018, s.20-21).

Kurumsal akademik arşivler, bilim insanlarının akademik ve bilimsel dergilerde yayınlanan veya kongre, konferans gibi bilimsel toplantılarda sunulan çalışmalarının elektronik kopyalarının açık arşive konması ve serbest erişime açılması ile oluşmaktadır. Genel olarak, kurumsal akademik arşiv sistemine bilimsel dergilerde yayınlanmış makaleler, yayınlanma aşamasında olan makaleler, kitaplar, bildiriler, elektronik tezler, teknik raporlar ve belgeler, istatistiksel raporlar, öğrenim materyalleri, kurumun yıllık raporları... vb. yayınlar ve dokümanlar ile birlikte (Afzali, 2009, s. 26-27), videolar, bilgi testleri, devam etmekte olan çalışmalar, ders sunumları, projeler, deney ve laboratuvar sonuçları, fotoğraflar, veri, plan, çizim gibi materyaller, açık erişim dergileri, yazılım ve bilgisayar programları, konferans metinleri ve görüntüleri de yüklenebilmektedir (Afzali ve Tonta, 2010, s. 156; Ertürk ve Küçük, 2010, s. 123-124). İçerikleri oldukça geniş olan kurumsal akademik arşivler; üniversitelerin entelektüel ürünlerini kayıt altına alarak koruyan dijital dermeler olarak da tanımlanabilmektedir. Aynı zamanda, kurumsal akademik arşivlerin erişim kısıtlaması olmaksızın bilgiyi arayan her bireye açık olması; yayın ve döviz kuru artışından doğrudan etkilenen kurum kütüphaneleri için faydalı bir model olarak kabul edilmektedir (Afzali ve Tonta, 2010, s. 155-156; Alav, 2019, s. 504-505).

\section{Tarihsel Gelişim}

Açık erişim düşüncesi ilk kez Stevan Harnad'ın 27 Haziran 1994'te bir tartışma platformunda paylaştığ1 "yıkıcı öneri" olarak adlandırdığı yazısında dile getirilmiştir. Bilimsel yayınların internet ortamında ücretsiz olarak sunulmasıyla başlayan bu düşünce, zamanla daha sistematik hale gelerek "açık erişim yayıncılık" faaliyetlerini ortaya çıkartmıştır (Afzali ve Tonta, 2010, s. 155). Ayrıca özellikle fen ve teknoloji alanında yayımlanan bilimsel dergi fiyatlarında yaşanan aşırı fiyat artışı, bilgi ve iletişim teknolojilerinde yaşanan gelişmeler de açık erişim fikrinin oluşup yaygınlaşmasına büyük katkı sağlamıştır. Tarih sürecinde özellikle 2000'li yılların başında açık erişim konusunda yapılan uluslararası toplantılar sayesinde açık erişim konusunda gelişmelerin kaydedildiği ve açık erişim hareketinin hedefine yönelik temellerin 
ortaya konulduğu görülmektedir. Bahsedilen toplantılardan ilki 2002 yılında gerçekleştirilen Budapeşte Açık Erişim Girişimidir. Bu toplantıda 'açık erişim' kavramı şu şekilde ifade edilmiştir:

"Açık erişimle, hakemli dergilerde yayımlanan makalelerin internet üzerinden ücretsiz olarak elde edilebilirliği ifade edilmektedir. Bu sistemde, herhangi bir kullanıcının bu makaleleri okuma, kaydetme, basma, çoğaltma-dağıtma, tarama ya da tam metinlerine link verme, dizinleme, veri olarak yazılımlara aktarma veya mali, yasal, internet ve herhangi bir teknik engel olmaksızın diğer başka yasal kullanımlarına izin verilir. Ancak tek sinırlama çoğaltma ve dă̆ıtım konusu ve bu alandaki telif hakkı için tek rol yazarlara, çalışmalarının bütünlüğ̈̈ üzerinde denetim sağlama, uygun bir biçimde kabul görme ve atıf yapma hakkını vermelidir" (Budapest Open Access Initiative, 2002'den aktaran; Dilek Kayaoğlu, 2006, s. $35)$.

Açık erişim üzerine yapılan bir diğer toplantı 11 Nisan 2003 tarihinde gerçekleştirilmiştir. Toplantıda alınan kararlar, 20 Haziran 2003 tarihinde 'Açık Erişim Yayıncılığg Üzerine Bethesda Bildirimi' adıyla yayımlanmıştır (Bethesda Statement on Open Access Publishing, 2003). Bethesda Bildiriminde, Budapeşte Açık Erişim Girişiminin üzerine yapılandırılmış bir açık erişim tanımı ortaya konulmuştur. Bununla birlikte bildirimde telif hakkı temelinde Budapeşte'de yapılan toplantıya nazaran bazı farklılıklar olduğu görülmektedir (Dilek Kayaoğlu, 2006, s. 35). Bethesda Bildirimi aynı zamanda uzun dönemde yazarların çalışmalarına erişim sağlanması için çalışmaların kurumların açık erişim arşivlerinde saklanması gerekliliğine de vurgu yapmaktadır (Bailey, 2006). Yine açık erişim girişimini güçlendirmek adına Berlin'de Max Planck Kurumu tarafından 22 Ekim 2003 tarihinde gerçekleştirilen toplantıda 'Fen ve Beşerî Bilimlerde Bilgiye Açık Erişsim Üzerine Berlin Bildirgesi' yayımlanmıştır (Berlin Declaration on Open Access to Knowledge in the Sciences and Humanities, 2003). Berlin Bildirgesi'nin Bethesda Bildirimi ile temelde ayn noktalara vurgu yaptığı ve birbirini desteklediği görülmektedir. Bu bildirgenin daha çok Alman araştırma kurumları tarafından imzalandığı dikkat çekmektedir (Dilek Kayaoğlu, 2006, s. 35). 2000'li yılların başlarında gerçekleştirilen bu toplantılar ve yayımlanan bildirgelerin dışında; yayıncılar, akademik çevreler ve konuyla ilgilenenlerin açık erişimden haberdar olmaları amacıyla, Birleşmiş Milletler 12 Aralık 2003 tarihinde Bilgi Toplumu Dünya Zirve Toplantısı Bildirgesini ve Ekonomik İşbirliği ve Kalkınma Örgütü (OECD), 30 Ocak 2004 tarihli Kamu Destekli Araştırma Verilerine Erişim Bildirgesi yayımlanmıştır (Tonta, 2007, s. 3; Alav, 2018, s. 75-76).

Açık erişimin dünyada giderek gelişmesi ve önem kazanmasında araştırma kurumları ve araştırma çalışmalarını destekleyen kuruluşların gerçekleştirdikleri açık erişim girişimleri ve politikaları son derece önemli rol oynamıştır. Bu çalışmalar arasında Avrupa Birliği tarafindan desteklenen OpenAIRE (Open Access Infrastructure Research in Europe), MedOANet (Mediterranean Open Access Networks) ve PASTEUR4OA (Open Access Policy Alignment Strategies for European Union Research) gibi dünyada ve Avrupa'da yürütülen önemli açık erişim girişimlerinden bahsetmekte fayda vardır.

2009 yılında 36 aylık bir proje olarak başlatılan, Avrupa Komisyonu, 7. Çerçeve Programı tarafından finanse edilen OpenAIRE projesi; Avrupa'daki açık erişim uygulamalarını destekleme ve harmanladığı kurumsal açık arşivlerin içeriğini bir ara yüzden araştırmacıların erişimine sunma amacını gütmektedir (OpenAIRE, 2013). Bu amaç 
Akademisyenlerin Açık Erişim ve Kurumsal Akademik Arşiv Konusunda Bilgi ve Farkındalık Düzeylerinin Belirlenmesi: Bartın Üniversitesi Uygulama Örneği

Determining the Level of Knowledge and Awareness of Academicians on Open Access and Institutional Repositories: An Example of Bartın University

doğrultusunda; OpenAIRE Projesi, Avrupa Araştırma Komisyonu Yedinci Çerçeve Programından fon desteği alan çalışmalara ait bilimsel çıktıların OpenAIRE Portalı'na dahil bir kurumsal veya konusal arşive yüklenmesini hedeflemektedir. $\mathrm{Bu}$ nedenle proje kapsamında 7. Çerçeve Programı ile destekli bilimsel araştırmaların tanımlanması, saklanması, erişimi ve görüntülenmesi için elektronik bir ara yüz ve destek mekanizması geliştirilmiştir (Gürdal, Türkfidanı, Kutlutürk, Sönmez ve Çelik, 2012).

Akdeniz Ülkeleri Açık Erişim Ağı olarak bilinen MedOANet, Avrupa'da bilimsel bilgiye açık erişim için eşgüdümlü strateji ve politikaların gerekliliği üzerinde duran, Avrupa Komisyonu 7. Çerçeve Programı tarafından Toplumda Bilim programıyla iki yıllığına (1 Aralık 2011-30 Kasım 2013) desteklenmiş bir projedir (Al ve Tonta, 2014, s. 434). MedOANet projesi, Mayıs 2010'da İspanya Güney Bilim ve Teknoloji Vakfi (FECYT: La Fundación Española para la Ciencia y la Tecnología) tarafından düzenlenen ve aynı vakfin ev sahipliğinde Güney Avrupa Kütüphaneleri Bağlantısının (SELL: Southern European Libraries Link) destekleri ile Granada'da yapılan “Güney Avrupa'da Açık Erişimi Geliştirme Politikaları" adlı seminerde kurulan bir ağ üzerine inşa edilmiştir. Bu projeyle birlikte hem altı Akdeniz ülkesindeki (Yunanistan, Türkiye, İtalya, Fransa, İspanya ve Portekiz) mevcut Açık Erişim politikaları, stratejileri ve yapılarının saptanarak güçlendirilmesi ve koordine edilmesi, hem de diğer Akdeniz ve Kuzey Avrupa ülkelerinde bilimsel bilgiye açık erişim, araştırmanın yayımı ve korunmasıyla ilgili ulusal ve bölgesel politika, strateji ve yapıların eşgüdümünün sağlanması hedeflenmiştir (MedOANet, 2012). Bu hedefler doğrultusunda; açık erişim ekosistemini haritalamak için anketler uygulanmış, ana paydaşlar bir araya getirilerek eşgüdümlü çalışmaları kolaylaştırmak için açık erişim çalıştayları düzenlenmiş, açık erişim politikalarını uygulamaya yönelik ilkeler ve öneriler geliştirilmiştir (MedOANet, 2013).

Açık adıyla Avrupa Birliği Araştırmaları Açık Erişim Politikası Uyum Stratejileri Projesi olan PASTEUR4OA'nın çalışmalarına Portekiz'de Minho Üniversitesi'nde 20-21 Şubat 2014 tarihlerinde yapılan bir toplantıyla başlanmış (Al ve Tonta, 2014, s. 434), final konferans1 17-18 Mayıs 2016'da Amsterdam'da gerçekleştirilmiştir (PASTEUR4OA, 2016). $\mathrm{Bu}$ projenin amacı kamu kaynakları ile yapılan araştırmalara açık erişim sağlanması adına, açık erişim politikalarının geliştirilmesidir. Avrupa Komisyonu'nun “bilimsel bilgilere erişim ve bilgilerin korunması" konulu tavsiyesi kapsamında PASTEUR4OA projesi, Avrupa Birliğinde açık erişim ve açık veri ile ilgili politikaların desteklenmesi ve geliştirilmesi amacını taşımaktadır (PASTEUR4OA, 2020). PASTEUR4OA projesi kapsamında desteklenen açık erişim politikalarının etkinliğinin değerlendirilebilmesi için ROARMAP 1 (Registry of Open Access Repository Mandates and Policies) dizini ile çalışılmış ve PASTEUR4OA projesi kapsamında mevcut her bir açık erişim politikası ROARMAP veri tabanında kayıt altına alınmıştır (PASTEUR4OA, 2015).

\footnotetext{
${ }^{1}$ ROARMAP kurumların oluşturduğu politikaları kategorik olarak kayıt altına alan bir açık erişim politikaları veri tabanıdır http://roarmap.eprints.org/ adresinden erişebilir.
} 
Açık erişim ve kurumsal açık arşiv konusunda günümüze kadar yapılan çalışma, uygulama ve projelere bakıldığında; hepsinin ortak özelliğinin kamu kaynakları kullanılarak yapılan araştırma sonuçlarına ve bilimsel yayınlara herkesin ücretsiz erişiminin sağlanması gayesi olduğunu söylemek mümkündür. $\mathrm{Bu}$ alanda yapılan çalışmalar, uygulamalar ve projeler aynı zamanda araştırmacıların, akademisyenlerin ve araştırma kurumlarının açık erişim kavramı ve onun temel uygulama modelleri olan açık erişim dergileri ve kurumsal açık arşivler konusunda farkındalık kazanmasına da katkı sağlamaktadır.

\section{Türkiye'de Açık Erişim ve Kurumsal Akademik Arşiv Konusunda Atılan Adımlar}

Genel olarak değerlendirildiğinde Türkiye'de açı erişim ve kurumsal akademik arşiv konusunda pek çok adım atıldığı görülmektedir. Ancak çalışmanın bu kısmında Türkiye'de bu konuda yapılan ilk çalışmalar ile YÖK (Yükseköğretim Kurulu) tarafından gerçekleştirilen güncel çalışmalara değinilmiştir.

Tarihsel olarak bakıldığında 2-4 Şubat 2005 tarihlerinde Gaziantep'te gerçekleştirilen Akademik Bilişim Konferansı'nda açık erişim konulu çağrılı konuşmanın bu konudaki ilk örneklerden biri olduğu görülmektedir. Daha sonra; Hacettepe Üniversitesi Bilgi ve Belge Yönetimi Bölümünde 2004-2005 eğitim öğretim yılı bahar döneminde doktora dersi kapsamında deneysel açık erişim arşivinin oluşturulması, yapılan ilk uygulamalı çalışmalardan biri olarak dikkat çekmektedir. Bu uygulama çalışmasında ilk olarak Bilgi ve Belge Yönetimi Bölümünde yapılan yüksek lisans/doktora tezleri ile öğretim üyelerinin yayınları Dublin Core Metadata Standardına göre arşive yüklenmiştir.

9-11 Aralık 2005 tarihlerinde İstanbul Bahçeşehir Üniversitesi'nde düzenlenen X. Türkiye'de İnternet Konferansı'nda, Türkiye'de açık erişim (AE) hareketinin ve kurumsal açık arşiv uygulamalarının birlikte yürütülmesi amacı ile "Açık Erişim Ulusal Politikası" oluşturulması kararlaştırılmıştır. Bu amacı gerçekleştirmek üzere, 09-11 Şubat 2006 tarihlerinde Pamukkale Üniversitesi'nde düzenlenen Akademik Bilişim konferansında üniversite kütüphanecilerini bir araya getiren e-kütüphane oturumlarının ana teması "Açık Erişim ve Kurumsal Arşivler” olmuştur. Çeşitli üniversitelerden kütüphanecilerin katılımıyla gerçekleşen oturumlarda, katılımcılar açık erişimin Türkiye'de yaygınlaştırılması için örnek olarak Berlin Bildirgesi'nin benimsenmesi gereğini bildirmişler ve bu toplantının sonunda “AB2006 Açık Erişim Bildirgesi” yayınlanmıştır (Afzali, 2009, s. 43-44). Türkiye'de açık erişim konusundaki ilk akademik makale ise Dilek - Kayaoğlu (2006) tarafından kaleme alınmıştır. $\mathrm{Bu}$ çalışmada; açık erişim kavramı, bildirgeler ve uygulama modelleri ile açıklanmış, açık erişimin ortaya çıkış nedenleri ve gelişimi incelenmiş, Türkiye için açık erişim fikri üzerinde durularak, açık erişime dayalı yayıncılık modelleri üzerine değerlendirmeler yapılmıştır.

Türkiye'deki açık erişim çalışmalarının gelişiminde 2012 yılından itibaren düzenli olarak her yıl gerçekleştirilen Ulusal Açık Erişim Çalıştayları son derece önemli bir yer tutmaktadır (Gürdal, Türkfidanı, Kutlutürk, Çelik ve Keten, 2012). 2014 yılı Ocak ayında YÖK "Yükseköğretim Akademik Arşiv Projesi”nin (YAAP) başlatılmasında bu çalıştayların rolü ve katkısı çok büyük olmuştur. Bu proje ile üniversitelerde üretilen bilimsel yayınların kurumsal akademik arşivlerde depolanarak açık erişime sunulması ve içeriklerinin YÖK tarafından harmanlanarak, merkezi olarak da erişilebilir kılınması amaçlanmıştır. Proje kapsamında 2014 yılında YÖK tarafından ülkemizdeki tüm üniversitelere gönderilen resmi 
Akademisyenlerin Açık Erişim ve Kurumsal Akademik Arşiv Konusunda Bilgi ve Farkındalık Düzeylerinin Belirlenmesi: Bartın Üniversitesi Uygulama Örneği

Determining the Level of Knowledge and Awareness of Academicians on Open Access and Institutional Repositories: An Example of Bartın University

yazı $^{2}$, üniversitelerimizin açık erişim politikalarını geliştirmesi sürecinde bir miladı teşkil etmektedir. 2014 yılında üniversitelere gönderilen bu yazı ile üniversitelerin standartlara uygun açık erişim sistemlerini kurmaları aynı zamanda kurumsal akademik arşiv politikalarını oluşturmaları istenmiş ve buna yönelik çalışma takvimi verilmiştir. Bu yazıdan sonra tüm üniversiteler kurumsal akademik arşiv sistemlerini kurmaya ve politikalarını geliştirmeye yönelik somut adımlar atmaya başlamalarına rağmen ilgili dönemde istenen verimin alınmadığı bilinmektedir. Atılan bu adımdan beş yıl sonra 2018 yılında "Açık Bilim ve Açık Erişim Çalışma Grubu" kurulmuştur. 25.12.2018 tarihinde Açık Bilim ve Açık Erişim Çalışma Grubu tarafından ilk toplantı yapılmış, Türkiye'deki tüm üniversitelerde uluslararası standartlarda "Açık Akademik Arşiv Sistemi” kurulması ve üniversite arşivlerinin Avrupa Açık Erişim Altyapısı (OpenAIRE) ile bütünleşmesi konularını gündeme almıştır. Bu noktada 2018 'in son ayları ve 2019 yılı Türkiye'de açık erişim ve kurumsal akademik arşivlerin geliştirilmesi konularında önemli bir dönüm noktası olmuştur. 2019 yılının şubat ayında YÖK tarafindan üniversitelere açık erişim ve kurumsal akademik arşivlerle ilgili resmi bir yazı gönderilmiştir. İlgili yazıda ${ }^{3}$ YÖK Türkiye'deki Üniversitelerden aşağıda genel hatları ile verilen konularda çalışmalar yapmasını istemektedir:

- Açık bilim ve açık erişim çalışmalarından sorumlu bir komisyon kurularak, üniversite çapında farkındalık toplantıları düzenlenmesi

- Üniversitelerde uluslararası standartlar çerçevesinde Açık Arşiv Sistemlerinin kurulması ve bu arşivin bir kütüphaneci sorumluluğunda yürütülmesi,

- Üniversitelerin Açık Bilim Politikalarını YÖK'ün işaret ettiği şekilde hazırlamaları,

- Handle üyeliğinin yapılması,

- Üniversitelerin akademik arşivlerinde OAI-PMH standartlarına göre veri üretilmesi ve arşiv sistemlerinin uluslararası harmanlama ve listeleme sistemlerine kayıtlı hale getirilmesi,

- Akademik arşive kayıtlı olan yazarlar için ORCID'lerin önemsenmesi,

- Akademik açık arşivlerin teşvik edilmesi için akademik yükseltme değerlendirmelerinde kullanılması,

- Yazarların yayın üretiminde açık erişim dergilerinin teşvik edilmesi,

- Açık ders malzemesi üretiminin teşvik edilmesi.

YÖK tarafından 2014 ve 2019 tarihlerinde yazılan iki yazı Türkiye'deki üniversitelerin açık erişim kavramı ve onun uygulamaları olan açık erişim dergi yayımlama ve kurumsal açık erişim arşiv politika ve çalışmalarına temel teşkil eden önemli yazılı kaynaklardır. Özellikle 2019 tarihli yazıdan sonra üniversiteler açık erişim ve kurumsal akademik arşiv konularında önemli çalışmalar yapmaya başlamıştır. Bu üniversitelerden birisi de Bartın Üniversitesi'dir.

\footnotetext{
${ }^{2}$ YÖK tarafindan ülkemizdeki tüm üniversitelere yazılan 02/04/2014 tarih ve 199557 sayılı resmi yazısı

${ }^{3}$ YÖK'ün 15.02.2019 tarih ve 36054236-806.02.04-06 sayılı Açık erişim ve kurumsal arşivlerle ilgili resmi yazisı.
} 
Türkiye'de son yıllarda akademisyenlerin açık erişim ve kurumsal açık arşivler konusundaki görüş ve farkındalıklarını inceleyen çalışmaların sayısının artması da dikkat çekicidir. Bu çalışmalar konu ile ilgili yapılan çalışma ve uygulamalara yön gösterici olmaktadırlar. Örneğin Ertürk ve Küçük (2010) Tarafından yapılan çalışmada Hacettepe Üniversitesi'ndeki akademisyenlerin açık erişim farkındalıkları ve kurumsal açık arşivler konusundaki görüşleri araştırılmaktadır. Çalışmada elde edilen bulgulara göre ankete yanıt veren akademisyenlerin yarısı (\%50) açık erişim farkındalığına sahiptir. Farkındalığı olan öğretim üyeleri yüksek bir çoğunlukla (\%92) yayınlarının kendi üniversitelerinde yapılandırılabilecek kurumsal açı arşivlerde yer almasına isteklidirler. Başkent Üniversitesinde görevli akademik personelin açık erişimli dergiler ve kurumsal açık arşivlerle ilgili bilinç ve tutumlarını ele alan yüksek lisans çalışmasında Odabaşoğlu (2016), üniversitede faaliyet gösteren akademik personelin açık erişim hakkında bilgi sahibi olduğunu, ancak kendi yayınları için çoğunlukla kurumsal açık erişim yayıncılığı tercih etmediklerini belirlemiştir. Bir başka yüksek lisans çalışmasında da (Aka, 2017), Fırat Üniversitesindeki öğretim elemanlarının açık erişim farkındalık düzeyinin düşük olduğu; öğretim elemanlarının açık erişim hakkında bilgi sahibi olduklarını düşünseler de konu ile ilgili ayrıntılı bilgi sahibi olmadıkları tespit edilmiştir. Araştırmada öğretim elemanlarının konu ile ilgili farkındalıklarının arttırılması için üniversite tarafından seminer, 'bilgilendirme toplantısı, konferans, panel, oryantasyon çalışmaları, 'kurum içi/hizmet içi eğitimler vb. etkinliklerin düzenlenmesi de önerilmiştir. Alaca, Büyükçolpan ve Kanık (2019) çalışmalarında, Ankara Yıldırım Beyazıt Üniversitesi (AYBÜ) akademisyenlerinin açık erişim, açık bilim ve kurumsal açık arşiv konularındaki farkındalık düzeylerini belirleyerek, kurumsal açık arşiv hizmetinden daha etkin yararlanmaları için öneriler geliştirmişlerdir. Araştırmada akademisyenlerin açık erişim konusundaki farkındalık düzeylerinin ve AYBÜ kurumsal açık arşivinden yararlanma düzeylerinin düşük olduğu ve buna rağmen büyük çoğunluğun bilgiye erişimde İnternet teknolojilerinden aktif olarak yararlandığı ve bilgiye ücretsiz erişimi desteklediği ortaya çıkmıştır. Ayrıca çalışmada akademisyenlerin büyük çoğunluğunun kurumsal açık arşivler konusunda bilgilendirilmek istediği de tespit edilerek, üniversite yönetiminin ve AYBÜ Kütüphane ve Dokümantasyon Daire Başkanlığının akademisyenleri kurumsal açık arşiv konusunda bilgilendirilmesi gerekliliği vurgulanmıştır.

$\mathrm{Bu}$ çalışmada da yukarıda bahsedilen çalışmalar gibi akademisyenlerin açık erişim ve kurumsal akademik arşiv konusundaki bilgi ve farkındalıkları incelenmiştir. Ancak çalışmada diğer çalışmalardan farklı olarak katılımcıların konu ile ilgili bilgi ve farkındalık düzeylerini yükseltmek amacıyla bir eğitim gerçekleştirilmiş ve akademisyenlerin eğitim öncesi ve sonrasında bu konudaki düşüncelerinde yaşanan değişimin incelenmesi amaçlanmıştır. Dolayısıyla diğer çalışmalardan farklı olarak tek örneklem ön test son test deseni kullanılmıştır. Çalışma bu yönüyle literatürde sık sık vurgulanan "açık erişim ve kurumsal akademik arşiv konusunda eğitimler verilmeli” önerisini uygulayarak sonuçlarını somut bir şekilde ortaya koymaktadır. Bu yönüyle çalışmanın konu ile ilgili yapılacak çalışmalara yeni bir bakış açısı kazandıracağı düşünülmektedir.

\section{Bartın Üniversitesi'nde Durum}

2008 yılında kurulan Bartın Üniversitesi bünyesinde 9 fakülte (Edebiyat Fakültesi, Eğitim Fakültesi, Fen Fakültesi, İktisadi ve İdari Bilimler Fakültesi, İslami İlimler Fakültesi, 
Akademisyenlerin Açık Erişim ve Kurumsal Akademik Arşiv Konusunda Bilgi ve Farkındalık Düzeylerinin Belirlenmesi: Bartın Üniversitesi Uygulama Örneği

Determining the Level of Knowledge and Awareness of Academicians on Open Access and Institutional Repositories: An Example of Bartin University

Mühendislik, Mimarlık ve Tasarım Fakültesi, Orman Fakültesi, Sağlık Fakültesi, Spor Fakültesi); 3 enstitü (Eğitim Bilimleri Enstitüsü, Fen Bilimleri Enstitüsü, Sosyal Bilimler Enstitüsü); 1 yüksekokul (Yabancı Diller Yüksekokulu)ve 3 meslek yüksekokulu (Bartın Meslek Yüksekokulu, Bartın Sağlık Hizmetleri Meslek Yüksekokulu, Ulus Meslek Yüksekokulu) barındırmaktadır. Üniversitenin akademik birimlerinde görev yapan 583 akademik personelin 32'si profesör, 49'u doçent, 186'sı doktor öğretim üyesi, 144'ü öğretim görevlisi ve 172'si araştırma görevlisidir. (Bartın Üniversitesi, 2020). ${ }^{4}$

Yükseköğretim Kurulu'nun yukarıda bahsedilen resmi yazıları, Türkiye'deki birçok üniversitede olduğu gibi Bartın Üniversitesi'nde de açık erişim konusundaki hizmet ve politikaların başlangıcı olmuştur. 2014 tarihli YÖK yazısı kapsamında üniversitede hızlı bir çalışma ile "Bartın Üniversitesi Açık Erişim Sistemi"5 faaliyete sunulmuştur. Aynı süreçte "Bartın Üniversitesi Açık Erişim ve Kurumsal Arşiv Politikası"” hazırlanarak yürürlüğe girmiştir. Ancak bütün bu çalışmalara rağmen 2014 yılından 2019 yılına kadar sisteme üye olan kullanıcı sayısı 74, girilen kayıt sayısı ise yalnızca 412 olmuştur.

YÖK tarafından gönderilen ikinci yazı sonrasında ise 2019 yılı içinde Bartın Üniversitesi Kütüphane ve Dokümantasyon Daire Başkanlığı ile Edebiyat Fakültesi Bilgi ve Belge Yönetimi Bölümü iş birliğinde düzenlenen "Kurumsal Akademik Arşiv Farkındalık ve Kullanıc1 Eğitimleri"” gerçekleştirilmiştir. Yaklaşık iki ay devam eden eğitimlerde, üniversitede görev yapan akademisyenlere açık erişim ve kurumsal akademik arşiv hakkında bilgiler verilerek, katılımcılara Bartın Üniversitesi Kurumsal Akademik Arşiv Sistemi Veri Giriş Adımları detaylı şekilde anlatılmıştır. Yapılan çalışmalar sonrasında Bartın Üniversitesi Kurumsal Akademik Arşiv Sistemine girilen kayıt sayısı 412'den 5556'ya yükselmiştir. ${ }^{8}$ Yapılan çalışmalarla bu alanda büyük bir başarının sağlandığı açıktır. Bununla birlikte bu rakamın da 583 akademisyeni ve 17.591 öğrencisi olan bir üniversite için yeterli olduğunu söylemek mümkün değildir. ${ }^{9} \mathrm{Bu}$ durumda araştırmanın temel amacı, Bartın Üniversitesi akademisyenlerinin üniversitenin açık erişim ve kurumsal akademik arşivi konusundaki mevcut bilgi ve farkındalıklarının belirlenmesi ile verilen eğitimin sonrasında akademisyenlerin bu konudaki bilgi ve farkındalıklarındaki değişimi incelemektir.

\section{Araştırmanın Yöntemi ve Tasarımı Araştırmanın Tasarımı}

Bartın Üniversitesi Edebiyat, Eğitim, İslami İlimler, Fen, Mühendislik Mimarlık ve Tasarım, Orman, İktisadi ve İdari Bilimler, Sağlık Bilimleri ve Spor Bilimleri Fakültelerindeki

\footnotetext{
${ }^{4}$ İlgili veriler 01.06.2020 tarihinde http://ubys.bartin.edu.tr/BIP/BusinessIntelligence/Officer/Academicians adresinden alınmıstır.

5 "Bartın Üniversitesi Açık Erişim Sistemi” için bkz. http://acikerisim.bartin.edu.tr:8080/xmlui/

6 "Bartın Üniversitesi Açık Erișim ve Kurumsal Arşiv Politikası" için bkz.

https://cdn.bartin.edu.tr/dspace/dspace-kurum-politika.pdf

${ }^{7}$ Bkz. https://w3.bartin.edu.tr/haberler/kurumsal-akademik-arsiv-farkindalik-ve-kullanici-egitimleri-

tamamlandi.html

${ }^{8}$ Bkz. http://acikerisim.bartin.edu.tr/

${ }_{9}^{9}$ Bkz. https://cdn.bartin.edu.tr/w3/739b8e61d1f02d96707d0f9c5d83ad1d/2020-yili-performans-programi.pdf
} 
akademisyenler ile Meslek Yüksekokullarında ve Yabancı Diller Yüksekokulundaki akademisyenlerin açık erişim ve kurumsal akademik arşiv konusundaki bilgi ve farkındalık düzeylerinin, verilen eğitimler sonucunda değişiminin belirlenmesine yönelik olarak yapılan araştırmada, tek gruplu ön test son test deseni kullanılmıştır. Çalışmada etik sorun oluşturabilecek sorular, maddeler, süreçler ya da unsurların olmadığına dair Bartın Üniversitesi Sosyal ve Beşerî Bilimleri Etik Kurulu tarafından 08.03.2019 tarihinde 2019-036 protokol numarası ile çalışmaya ait etik kurul onayı alınmıştır. Çalışma, Üniversitenin bünyesindeki 9 fakülte, 3 meslek yüksekokulu ve 1 yüksekokulunda 2019 yılında yürütülmüştür. İlgili birimlere açı erişim ve kurumsal akademik arşiv kapsamında bilgilendirme eğitimleri verilmiştir. Eğitimlerden önce akademisyenlere ön test anketleri uygulanmış, eğitimden 2 hafta sonra eğitime katılan akademisyenlere son test uygulaması yapılmıştır.

\section{Veri Toplama Aracı}

Veri toplama aracı olarak araştırmacılar tarafından oluşturulan anket kullanılmıştır. Anket soruları hazırlanırken mevcut literatürden yararlanılmıştır (Açık Erişim Farkındalık ve Memnuniyet Anketi Sonuç Raporu, 2015; Yang ve Li; 2015; Odabaşoğlu, 2017; Alaca, Büyükçolpan ve Kanık, 2019). Araştırmacılar tarafından hazırlanan anket sorularının uygunluğu, soruluş sırası, anlaşılırlığı ve amacına uygunluğunun değerlendirilmesi amacı ile 3 üç alan uzmanı ve 1 dil uzmanından görüş alınmıştır. Alan uzmanlarının görüşleri doğrultusunda yeniden sorular gözden geçirilerek çalışmanın kapsam geçerliliği sağlanmaya çalışılmıştır.

Anket formu üç ana bölümden oluşmaktadır. Birinci bölümde demografik bilgiler toplanmış, ikinci bölümde açık erişim ve kurumsal akademik arşivler hakkında kategorik sorulara yer verilmiştir. Ayrıca son teste verilen eğitim hakkında akademisyenlerin görüşlerini almaya yönelik sorular eklenmiştir. Anketin son bölümünde açık erişim ve kurumsal akademik arşivlerin bilimsel iletişime etkilerini değerlendiren maddelere yer verilmiştir. Maddelere katılım düzeyinin ölçülmesi için 5'li Likert ölçeği kullanılmıştır. 5'li Likert ölçeğinde, "kesinlikle katılıyorum-5", "katılıyorum-4", "ne katılıyorum ne katılmıyorum-3", "katılmıyorum-2", "kesinlikle katılmıyorum-1" şeklinde beş seçenek yer almaktadır. Anketin son bölümü eğitim öncesinde ve sonrasında tekrar uygulanmıştır.

\section{Evren ve Örneklem}

Çalışmanın örneklemini Bartın Üniversitesi Edebiyat Fakültesi, Eğitim Fakültesi, İslami İlimler Fakültesi, Fen Fakültesi, Mühendislik, Mimarlık ve Tasarım Fakültesi, Orman Fakültesi, İktisadi ve İdari Bilimler Fakültesi, Sağlık Bilimleri Fakültesi, Spor Bilimleri Fakültesi akademisyenleri ile Yüksekokullarda görev yapan 284 akademisyen oluşturmaktadır. Evreni temsil eden Bartın Üniversitesi toplam akademik personel sayısı 583'tür. Araştırmacılar güven düzeyi olarak \%95'i, (alfa=0,05 için $\mathrm{t}=1,96)$, evren için tahmin edilen standart sapma değerini 0,5 olarak almıştır. Bu temelde nicel değişkenli araştırmalar için Bartlet, Körtlink ve Higgins'in (2001) örneklem hesaplaması kullanılmıştır.

$n_{0}=\frac{t^{2} x^{s}}{d^{2}} \quad n=\frac{n_{0}}{1+n_{0} / N}$ 
Akademisyenlerin Açık Erişim ve Kurumsal Akademik Arşiv Konusunda Bilgi ve Farkındalık Düzeylerinin Belirlenmesi: Bartın Üniversitesi Uygulama Örneği

Determining the Level of Knowledge and Awareness of Academicians on Open Access and Institutional Repositories: An Example of Bartın University

$\mathrm{Bu}$ araştırma için yukarıdaki hesaplamaya göre 231 kişilik örneklem büyüklüğü yeterli olmaktadır. Araştırmacıların bulmuş olduğu bu sayıya örneklemden dönmeyecek anket miktarı ve geri dönen anketlerin bir kısmının eksik doldurulabileceği ve veri analizi için uygun olmayacağı gözetilerek ihtiyat payı eklenmiş ve 300 akademisyene anket uygulaması yapılmıştır. 300 anket üzerinden 284 âdeti kullanılabilir bulunmuştur. Örneklemin evreni temsil etme oranı \%48,7 iken örneklem içerisinden geri dönüş oranı \%94,7'dir. Örneklemin evreni temsil etme oranı, çalışmanın güvenilirliği açısından yeterlidir (Altunışık, Coşkun, Bayraktaroğlu ve Yıldırım, 2012, s. 137).

\section{Verilerin Analizi}

Araştırma verileri, kodlanarak SPSS 22.0 programına kaydedilmiştir. Bulguların yorumlanmasında $\mathrm{p}$ değeri 0,05 anlamlılık düzeyi esas alınmıştır. Çalışma kapsamında akademisyenlere açık erişim ve kurumsal açık arşivler konusunda eğitim verilerek Bartın Üniversitesi Kurumsal Akademik Arşivi tanıtılmıştır. Bartın Üniversitesi bünyesindeki 9 fakülte, 3 meslek yüksekokulu ve 1 yabancı diller yüksekokulunun akademisyenlerine 'açık erişim ve kurumsal akademik arşiv' konusundaki bilgi ve farkındalıkları ile eğitim sonrası farkındalıklarındaki değişimi belirlemeye yönelik olarak 284 kişiye eğitim verilerek, ön test ve son test uygulaması yapılmıştır. Yapılan Anketin Cronbach Alfa Güvenirlik katsayısı; 0,888 olarak bulunmuştur.

Çalışmanın ilk kısmında akademisyenlere verilen eğitimin öncesinde akademisyenlerin açık erişim ve kurumsal akademik arşivler konusunda mevcut bilgilerini araştıran ön test yapılmıştır. Verilen eğitimden sonra akademisyenlerin bu konudaki düşüncelerinde farklılık gösterip göstermediği istatistiksel olarak analiz edilmeden önce anket sonuçlarının normal dağılım gösterip göstermediği "Kolmogorov Smirnov Testi” kullanılarak değerlendirilmiştir. Yapılan analizden elde edilen anlamlılık değeri (Assymp. Sig. $=p=0,00$, $\mathrm{p}<0,05)$ sonucunda parametrik olmayan test yöntemleri kullanılmıştır. Bu çalışmada; sayısal verilerin sunulmasında betimleyici analizler kullanılmış, eğitim öncesi ve sonrası ilgili konuda bilgi değişikliğinin olup olmadığını ölçmek amacı ile Wilcoxon işaretli sıralar testi yapılmıştır.

\section{Bulgular}

\section{Demografik Bulgular}

Akademisyenlere uygulanan ankette; katılımcıların cinsiyeti, çalıştıkları bölümler, unvanları ve çalışma sürelerine ilişkin tanımlayıcı veriler elde edilmiştir. Katılımcıların demografik özelliklerine ilişkin tanımlayıcı istatistikler Tablo 1'de sunulmuştur. 
Tablo 1

Katılımcıların demografik özelliklerine ilişkin tanımlayıcı istatistikler

\begin{tabular}{|c|c|c|}
\hline Cinsiyet & Frekans & Yüzde \\
\hline Kadın & 119 & 41,9 \\
\hline Erkek & 165 & 58,1 \\
\hline Toplam & 284 & 100 \\
\hline Bölüm & Frekans & Yüzde \\
\hline Edebiyat Fakültesi & 49 & 17,3 \\
\hline Eğitim Fakültesi & 43 & 15,1 \\
\hline Mühendislik, Mimarlık ve Tasarım Fakültesi & 37 & 13 \\
\hline Fen Fakültesi & 19 & 6,7 \\
\hline İslami İlimler Fakültesi & 19 & 6,7 \\
\hline İktisadi ve İdari Bilimler Fakültesi & 19 & 6,7 \\
\hline Orman Fakültesi & 13 & 4,6 \\
\hline Sağlık Bilimleri Fakültesi & 7 & 2,5 \\
\hline Spor Bilimleri Fakültesi & 10 & 3,5 \\
\hline Meslek Yüksek Okullar & 53 & 18,6 \\
\hline Yabancı Diller Yüksek Okulu & 15 & 5,3 \\
\hline Toplam & 284 & 100 \\
\hline Unvan & Frekans & Yüzde \\
\hline Öğretim Görevlisi & 63 & 22,2 \\
\hline Araştırma Görevlisi & 62 & 21,8 \\
\hline Öğretim Görevlisi Dr. & 16 & 5,6 \\
\hline Araştırma Görevlisi Dr. & 16 & 5,6 \\
\hline Doktor Öğretim Üyesi & 90 & 31,7 \\
\hline Doçent Dr. & 23 & 8,1 \\
\hline Prof. Dr. & 14 & 4,9 \\
\hline Toplam & 284 & 100 \\
\hline Deneyim & Frekans & Yüzde \\
\hline $1-5 \mathrm{y} 11$ & 114 & 40,1 \\
\hline 6-10 y1l & 113 & 39,8 \\
\hline $11-15$ yil & 15 & 5,3 \\
\hline $16-20$ yil & 20 & 7 \\
\hline $21-25$ y1l & 17 & 6 \\
\hline $26-30$ y1l & 5 & 1,8 \\
\hline Toplam & 284 & 100 \\
\hline
\end{tabular}


Akademisyenlerin Açık Erişim ve Kurumsal Akademik Arşiv Konusunda Bilgi ve Farkındalık Düzeylerinin Belirlenmesi: Bartın Üniversitesi Uygulama Örneği

Determining the Level of Knowledge and Awareness of Academicians on Open Access and Institutional Repositories: An Example of Bartın University

Tablo 1 genel olarak değerlendirildiğinde, katılımcıların; \%58,1'inin erkek, \%41,9'unun kadın olduğu görülmektedir. Katılımcıların \%18,6'sının Meslek Yüksek Okullarında, \%17,3'ünün Edebiyat Fakültesinde, \%15,1'nin Eğitim Fakültesinde, \%13'ünün Mühendislik Fakültesinde görevli öğretim elemanı olduğu tespit edilmiştir. Katılımcılar unvanlarına göre değerlendirildiğinde \%37,7'sinin Dr. Öğretim Üyesi, \%27,8'inin Öğretim Görevlisi ve Doktor unvanını almış Öğretim Görevlisi olduğu, \%27,4’ünün Araştırma Görevlisi ve Doktor unvanını almış Araştırma Görevlisi olduğu görülmektedir. Katılımcıların \%13'ünün Doçent ve Profesör unvanına sahip öğretim üyelerinin oluşturduğu belirlenmiştir. $\mathrm{Bu}$ oranın üniversitenin kadro yapısı ile paralellik gösterdiğini söylemek mümkündür. Katılımcıların unvanlarına benzer şekilde üniversite deneyimine sahip olduğu görülmektedir. Katılımcıların yıllara göre mesleki deneyimlerine bakıldığında; en çok \% 40,1 oranında 1-5 y1l ve \% 39,8 oranında 6-10 yı1lık deneyim sahibi oldukları görülmektedir. Katılımcı akademisyenlerin çoğunluğunun mesleki deneyimlerinin 10 yılın altında olduğu tespit edilmiştir.

\section{Sosyal Akademik Ăğların Kullanımı}

Eğitim öncesinde katılımcı akademisyenlere yönlendirilen sorulardan ilk ikisi sosyal akademik ağlara ilişkindir. Bilimsel iletişimi kolaylaştırmak amacı ile oluşturulan bu platformlara Bartın Üniversitesi akademisyenlerinin yaklaşımı sorgulanmıştır. İlgili sorular ve katılımcıların verdiği cevaplar Tablo 2'de sunulmaktadır.

Tablo 2

Akademisyenlerin sosyal akademik ăglarla olan ilişkileri

\begin{tabular}{|c|c|c|}
\hline Academia veya Research Gate benzeri platformları aktif olarak kullanıyorum. & Frekans & Yüzde \\
\hline Evet & 218 & 76,8 \\
\hline Kararsızım & 29 & 10,2 \\
\hline Hayır & 37 & 13 \\
\hline Toplam & 284 & 100 \\
\hline $\begin{array}{l}\text { Academia veya Research Gate benzeri platformların çalışmalarımın } \\
\text { görünürlüğünü artırdığını düşünüyorum. }\end{array}$ & Frekans & Yüzde \\
\hline Evet & 225 & 79,2 \\
\hline Kararsızım & 42 & 14,8 \\
\hline Hayır & 17 & 6 \\
\hline Toplam & 284 & 100 \\
\hline
\end{tabular}

Tablo 2'de, akademisyenlerin sosyal akademik ağların kullanımı hakkındaki görüşleri değerlendirilmiştir. Katılımcıların \%76,8'inin Academia veya Research Gate gibi benzeri platformları aktif olarak kullanırken, \%13'ünün bu platformları aktif olarak kullanmadığı, \%10,2'sinin ise sosyal akademik ağları kullanmakta kararsız olduğu tespit edilmiştir. Aynı tabloda katılımcıların \%79,2'sinin Academia veya Research Gate benzeri platformların akademisyenlerin bilimsel çalışmalarının görünürlügünü artırdığını düşündüğü, \%14,8'inin bu konuda kararsız olduğu ve \%6'sının bu konuda negatif görüş bildirdiği tespit edilmiştir. 
Bulgulara göre, akademisyenlerin büyük bir çoğunluğu, Academia veya Research Gate gibi sosyal akademik ağları faydalı bulmakta ve bu platformların bilimsel anlamda görünürlüğü artırdığını düşünmektedirler.

\section{Bartın Üniversitesi Kurumsal Akademik Arşivi Aktif Kullanım Oranı}

Bartın Üniversitesi akademisyenlerinden oluşan katılımcılara Bartın Üniversitesi Kurumsal Akademik Arşivi ile ilgili sorular yönlendirilmiştir. Yönlendirilen ilk ve bağlantılı soru Bartın Üniversitesi Kurumsal Akademik Arşivinde kayıtlı olup olmadıklarına ilişkindir. Bu soruya ilişkin olarak verilen cevaplar Grafik1'de sunulmuştur.

— Bartın Üniversitesi Kurumsal Arşivine kay 1tlı hesab im y ok

- Bartın Üniversitesi Kurumsal Arşivine kay ıtlı hesabım var ve yükleme yaptım

nartın Üniversitesi Kurumsal Arşivine kay ıtlı hesabım var ancak yükleme y apmadım

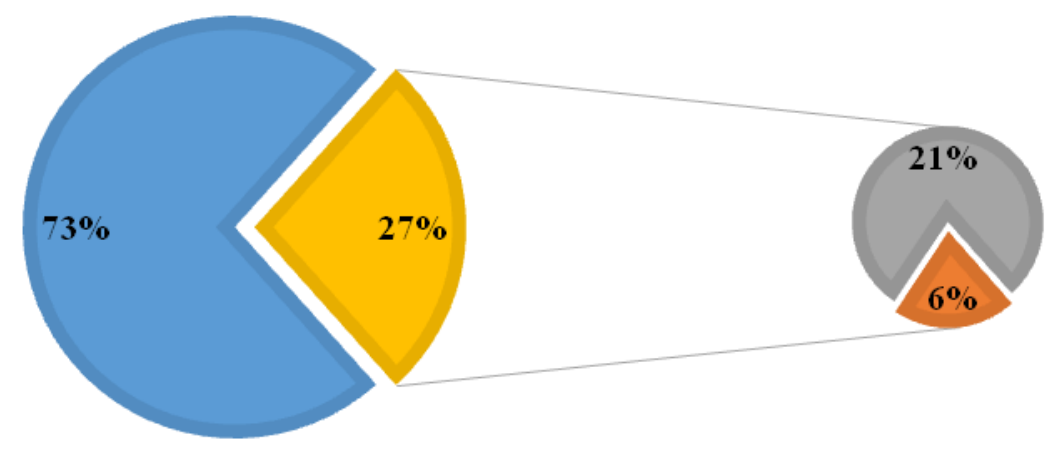

Grafik 1. Bartın Üniversitesi kurumsal akademik arşiv kullanım dağılımı.

Grafik 1 değerlendirildiğinde katılımcı akademisyenlerin \%73'nün Bartın Üniversitesi Kurumsal Akademik Arşivinde kayıtlı hesabı olmadığı tespit edilmiştir. Bu cevap aynı zamanda akademisyenlerin kurumsal akademik arşive daha önce yayın yüklemediklerinin de göstergesidir. Katılımcı akademisyenlerin sadece \%27'sinin Bartın Üniversitesi Kurumsal Akademik Arşivinde kayıtlı hesapları olduğu ancak bu akademisyenlerin çok küçük bir oranının arşive yayın yüklediği görülmektedir. $\mathrm{Bu}$ oran ise çalışmaya katılan tüm akademisyenlerin \%6'sını oluşturmaktadır.

Öğretim üyelerinin Bartın Üniversitesi Kurumsal Akademik Arşivinde kayıtlı hesaplarının bulunmaması veya kurumsal akademik arşive yayın yüklememe nedenleri sorgulanmıştır. İlgili cevaplar Tablo 3 'te sunulmaktadır. 
Akademisyenlerin Açık Erişim ve Kurumsal Akademik Arşiv Konusunda Bilgi ve Farkındalık Düzeylerinin Belirlenmesi: Bartın Üniversitesi Uygulama Örneği

Determining the Level of Knowledge and Awareness of Academicians on Open Access and Institutional Repositories: An Example of Bartın University

Tablo 3

Kurumsal akademik arşivin aktif kullanılmamasina ilişkin nedenler

\begin{tabular}{lll}
\hline & Frekans & Yüzde \\
\hline Zaman bulamıyorum & 54 & 19 \\
Nasıl yayın yükleneceğini bilmiyorum & 155 & 54,6 \\
Unutuyorum & 19 & 6,7 \\
Akademik yükseltmelerde etkisiz olduğu için & 13 & 4,6 \\
Yasal çekincelerim var & 15 & 5,3 \\
Diğer & 28 & 9,9 \\
Toplam & $\mathbf{2 8 4}$ & $\mathbf{1 0 0}$
\end{tabular}

Akademisyen katılımcıların \%54,6'sı üniversitenin kurumsal akademik arşivine nasıl yayın yükleneceğini ve nasıl kullanılacağını bilmedikleri için arşivi kullanmadıklarını ve yayın yüklemediklerini belirtmişlerdir. $\mathrm{Bu}$ oran oldukça fazladır ve katılımcıların yarıdan fazlasının kurumsal akademik arşive nasıl yayın yükleneceğini bilmediklerinden dolayı kurumsal akademik arşivi kullanmadıklarını göstermektedir. Yayın yüklemeyenlerin \%19'u zamansızlıktan, \%6,7'si bu işlemi yapmayı unuttuğundan, \%5,3'ü yasal çekincelerinden, $\% 4,6$ 's1 akademik yükseltmelerde etkisiz olduğundan ve \%9,9'u diğer nedenleri (örneğin; kötü amaçlı kullanım) gerekçe göstererek yüklemediklerini belirtmişlerdir.

Akademisyenlere Bartın Üniversitesi Kurumsal Akademik Arşivinin verimli çalışamamasındaki temel sebebin ne olabileceği sorulmuş, verilen cevaplar Tablo 4'te sunulmuştur.

Tablo 4

Kurumsal akademik arşivin etkili olarak çalışamamasına ilişkin nedenler

\begin{tabular}{lll}
\hline & Frekans & Yüzde \\
\hline İletişim yetersizliği & 97 & 34,2 \\
Eğitim/bilgilendirme yetersizliği & 96 & 33,8 \\
Sistem ve politika yetersizliği & 20 & 7 \\
Akademisyenlerin ihmali & 32 & 11,3 \\
Kurumsal aidiyet eksikliği & 19 & 6,7 \\
Bütçe & 8 & 2,8 \\
Diğer & 12 & 4,2 \\
Toplam & $\mathbf{2 8 4}$ & $\mathbf{1 0 0}$ \\
\hline
\end{tabular}

Katılımcılara üniversitenin kurumsal akademik arşivini daha etkili hale getirebilmek için neler yapılması gerektiği sorulduğunda katılımcıların, \%34'ü üniversitenin kütüphanesi ve akademik birimleri ile akademisyenler arasındaki iletişim eksikliğinin giderilmesi gerektiğini belirtirken, katılımcıların \%33,8'i akademisyenlerin bu konuda bilgilendirilmediğini ve gerekli eğitimlerin verilmediğini belirtmişlerdir. Katılımcılar, kurumsal akademik arşivin etkili kullanılamamasının bir diğer sebebi olarak akademisyenlerin kurumsal olarak aidiyet hissetmemesini gerekçe göstermişlerdir (\%6,7). Kurumsal akademik 
arşivin verimli olarak çalışamamasında katılımcıların gösterdiği diğer gerekçeler ise sırası ile sistem ve politika yetersizliği $(\% 7)$, bütçe sıkıntısı $(\% 2,8)$ ve diğer nedenler $(\% 4,2)$ olarak belirtilmiştir.

Anket kapsamında katılımcılara daha önce açık erişim ve kurumsal akademik arşivlere yönelik bir eğitim, seminer ve benzeri toplantıya katılıp katılmadıkları, katıldılar ise toplantının içeriğinin ne olduğu sorulmuştur. Katılımcılardan alınan cevaplar Grafik 2'de sunulmuştur. Grafik 2'den anlaşılacağı üzere Katılımcıların \%94'ü daha önce açık erişim ve kurumsal akademik arşivlerin içerik, fayda ve kullanımı konusunda herhangi bir eğitime katılmadığı tespit edilmiştir. Daha önce bu konuda eğitim alanların oranı ise sadece $\% 6$ 'dır. Eğitim alanlar bu konuda seminer $(\% 3,9)$, çalıştay $(\% 0,7)$, panel $(\% 0,7)$ ve kurum dişında kurslar $(\% 0,7)$ aracılığ

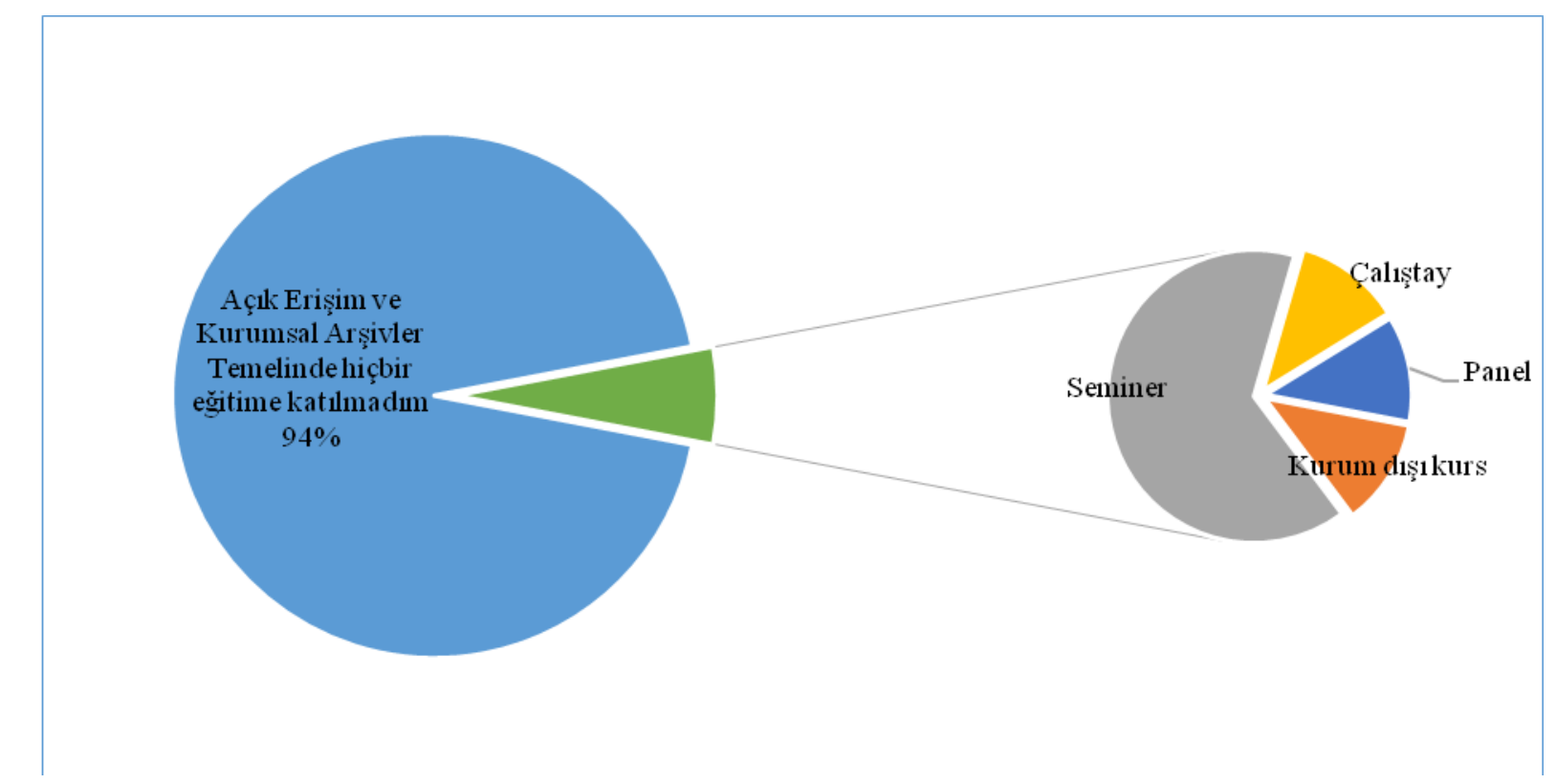

Grafik 2. Açık erişim ve kurumsal akademik arşiv konusunda eğitim ve toplantıya katılım durumları.

\section{Ĕ̌̆itim Sonrası Akademisyenlerin Görüşleri}

Eğitimden 2 hafta sonra akademisyenlere açık erişim ve kurumsal akademik arşivlere ilişkin mevcut görüşlerinin ne yönde değişikliğe uğradığını değerlendirebilmek amacı ile bazı sorular sorulmuştur. Katılımcılara yönlendirilen sorular ve sorulara ilişkin cevaplar Tablo 5 'te sunulmaktadır. Tablo 5 üzerinde kesinlikle katıllyorum ifadesi, 5; katıllyorum ifadesi, 4; ne katılıyorum ne katılmıyorum ifadesi, 3; katılmıyorum ifadesi, 2; kesinlikle katılmıyorum ifadesi, 1 olarak kodlanarak sunulmuştur. 
Akademisyenlerin Açık Erişim ve Kurumsal Akademik Arşiv Konusunda Bilgi ve Farkındalık Düzeylerinin Belirlenmesi: Bartın Üniversitesi Uygulama Örneği

Determining the Level of Knowledge and Awareness of Academicians on Open Access and Institutional Repositories: An Example of Bartin University

Tablo 5

Eğitim sonrası akademisyenlerin görüşlerine iliş̧kin oranlar (\%)

\begin{tabular}{|c|c|c|c|c|c|}
\hline & 5 & 4 & 3 & 2 & 1 \\
\hline S1: Eğitim Seminerinin fayda sağladığını düşünüyorum. & 53,9 & 38,0 & 3,5 & 2,1 & 2,5 \\
\hline $\begin{array}{l}\text { S2: Eğitim sonrasında açık erişim konusundaki düşüncelerimde } \\
\text { olumlu değişiklik oldu. }\end{array}$ & 43,3 & 43,7 & 8,1 & 2,1 & 2,8 \\
\hline $\begin{array}{l}\text { S3: Eğitim sonrasında üniversitemizin kurumsal akademik arşivi } \\
\text { hakkındaki düşüncelerimde olumlu değişiklik oldu. }\end{array}$ & 45,4 & 40,1 & 10,2 & 1,8 & 2,5 \\
\hline $\begin{array}{l}\text { S4: Bu eğitimden sonra telif sorunu bulunmayan yayınlarımı Bartın } \\
\text { Üniversitesi Açık Erişim ve Kurumsal Akademik Arşivi'ne } \\
\text { yüklemeyi düşünüyorum. }\end{array}$ & 37,7 & 46,1 & 11,6 & 2,8 & 1,8 \\
\hline $\begin{array}{l}\text { S5: Kütüphane tarafından belirli periyotlarla Bartın Üniversitesi Açık } \\
\text { Erişim ve Kurumsal Akademik Arşivi'nin daha yaygın kullanılması } \\
\text { için akademisyenlere ve öğrencilere yönelik bilgilendirmeler } \\
\text { yapılmalıdır. }\end{array}$ & 43,7 & 45,4 & 4,9 & 3,2 & 2,8 \\
\hline $\begin{array}{l}\text { S6: Eğitim sonrasında Bartın Üniversitesi Kurumsal Akademik } \\
\text { Arşivini kullanacak kadar teknik bilgi kazandım. }\end{array}$ & 33,5 & 45,4 & 14,8 & 5,3 & 1,1 \\
\hline $\begin{array}{l}\text { S7: Üniversite kütüphanelerinin açık erişim ve kurumsal akademik } \\
\text { arşivlerinin daha etkin kullanılması için akademisyenlere eğitsel } \\
\text { destek sağlamasının gerekli olduğunu düşünüyorum. }\end{array}$ & 39,1 & 48,6 & 8,5 & 3,2 & 0,7 \\
\hline $\begin{array}{l}\text { S8: Akademisyenlere açık erişim ve kurumsal akademik arşivlerin } \\
\text { daha etkin kullanılması için teknolojik destek sağlamasının gerekli } \\
\text { olduğunu düşünüyorum. }\end{array}$ & 38,7 & 48,9 & 9,2 & 2,5 & 0,7 \\
\hline
\end{tabular}

Tablo 5 akademisyenlerin ilgili sorulara verdikleri cevapların katılım yüzdelerini açık olarak sunmaktadır. Daha önce de belirtilmiş olduğu üzere maddelere katılım düzeyinin ölçülmesi için 5'li Likert ölçeği kullanılmıştır. Akademisyenlerin maddelere "kesinlikle katılıyorum" olarak verdiği cevap 5 ile puanlanırken, "kesinlikle katılmıyorum" olarak verdikleri cevaplar 1 ile puanlanmıştır. Tablo 5 'in yorumlanmasında akademisyenlerin 5 üzerinden aldıkları ortalama puanlar üzerinden de değerlendirme yapılmıştır.

Tablo 5'te Soru 1'e verilen yanıtlardan görüldüğü üzere katılımc1lar kendilerine verilen Açık Erişim ve Kurumsal Akademik Arşivler ile ilgili eğitimleri büyük oranda faydalı bulmuşlardır. 'Eğitim Seminerinin fayda sağladığını düşünüyorum.' şeklindeki ilk soruya verilen cevap ortalaması 4,39'dur. Bu ortalama katılımcıların eğitimi faydalı bulduğu, verilen cevapların kesinlikle katılıyorum ile katılıyorum cevapları arasında değiştiğini göstermektedir Kesinlikle katıliyorum ve katıliyorum cevaplarını veren katılımcılar tüm katılımcıların \%91,9'unu oluşturmaktadır. Nitekim bu durum katılımcıların verdikleri cevapların yüzdelerinden kolayca anlaşılabilmektedir. Bu ortalama eğitimin başarılı olduğunu gösterir niteliktedir.

Soru 2 ve 3'e verilen cevaplar değerlendirildiğinde; eğitim sonrasında katılımcıların hem açık erişim hem de kurumsal akademik arşivlerle ilgili mevcut bilgilerinde eğitim sonrasında pozitif yönde değişiklik olduğunu belirttikleri anlaşılmaktadır. Katılımcılar, açık erişim ve kurumsal akademik arşivlere ilişkin olarak kendilerine yönlendirilen sorulara (S2- 
S3) sırası ile 4,23 ve 4,24 ortalama ile cevaplandırmışlardır. Bu ortalama ilgili sorulara verilen cevapların katılıyorum ve kesinlikle katıllyorum cevapları arasında çeşitlendiğini göstermektedir. Kaldı ki bu durum akademisyenlerin ilgili sorulara verilen cevaplardaki katılım yüzdelerinden de anlaşılabilmektedir. 2. Soruya kesinlikle katıllyorum ve katıllyorum cevaplarını veren katılımcıların oranı tüm katılımcıların \%87'sini, 3. soruya kesinlikle katıliyorum ve katıllyorum cevaplarını veren katılımcılar tüm katılımcıların \%85,5'ini oluşturmaktadır.

Katılımcılara eğitim sonrasında kurumsal akademik arşive yayın yüklemeye ilişkin olarak yönlendirilen 4. soruya verilen yanıt ortalamasının $(4,15)$ diğer sorulardan alınan ortalamalar kadar yüksek olmaması, katılımcıların halen yasal açıdan bazı çekincelerinin olduğunu göstermektedir. Bu soruya kesinlikle katıllyorum ve katıllyorum cevaplarını veren katılımcılar tüm katılımcıların \%83,8'ini oluşturmaktadır.

Katılımcıların kendilerine verilen bu eğitim seminerini değerlendirmesi kapsamında kendilerine yönlendirilen bir diğer soru eğitim ve bilgilendirmeler ile ilgilidir (S5). Bu sorudan alınan cevaba göre katılımcılar belirli aralıklar ile hem akademisyenlere hem de öğrencilere üniversitenin açık erişim ve kurumsal akademik arşivinin kullanımına yönelik olarak bilgilendirme yapılması görüşüne büyük oranda katıldıkları görülmektedir. İlgili sorunun cevap ortalaması 4,23 olarak tespit edilmiştir. Bu soruya kesinlikle katıllyorum ve katıllyorum cevaplarını veren katılımcılar tüm katılımcıların \%89,1'ini oluşturmaktadır.

Akademisyenlere yönlendirilen "Eğitim sonrasında Bartın Üniversitesi Kurumsal Akademik Arşivini kullanacak kadar teknik bilgi kazandım” ifadesine katılım ortalaması 4,05 olarak tespit edilmiştir. Bu ifadeyi içeren 6.soruya, kesinlikle katıllyorum ve katıllyorum cevaplarını veren katılımcılar, tüm katılımcıların \%78,9'unu oluşturmaktadır. Akademisyenlere yönlendirilen ifadeler arasında kesinlikle katıllyorum ve katıllyorum cevaplarında en düşük toplam katılım yüzdesi alan bu ifade, akademisyenlerin teknik anlamda eğitim sonrasında halen bazı sorunlar yaşadıklarını tanımlar niteliktedir. Benzer şekilde akademisyenlere yönlendirilen son iki (S7- S8) ifade de 6. sorudan alınan cevapları desteklemektedir. Son iki ifade ile kurumsal akademik arşivin daha etkili kullanılabilmesi için akademisyenlere eğitsel (7. soru) ve teknik (8. soru) destek verilmesi konusunda katılımcıların görüşleri araştırılmıştır. Akademisyenlerin \%87,7'si eğitsel, \%87,6's1 teknik destek verilmesi konusundaki ifadelere kesinlikle katılyyorum ve kattliyorum cevaplarını verdikleri görülmektedir. Başka bir ifade ile akademisyenlerin büyük çoğunluğu eğitsel ve teknik destek eğitimlerinin verilmesi fikrine katılmaktadır.

\section{Ön Test Son Test Bulgulart}

Açık erişim ve kurumsal akademik arşivler temelinde akademisyenlere verilen eğitimden önce ve sonra katılımcıların bilgi ve farkındalıklarını değerlendirebilmek adına bir anket yapılmıştır. Böylece akademisyenlerin açık erişim ve kurumsal akademik arşivler konusundaki mevcut bilgileri saptanmış ve eğitimden sonra ilgili konudaki görüşlerinin nasıl değiştiği araştırılmıştır. Bu amaç doğrultunda akademisyenlerin açık erişim ve kurumsal akademik arşivler konusundaki düşüncelerinin ön test-son test puanları arasındaki farkın anlamlılığını test etmek için Wilcoxon işaretli sıralar testi yapılmıştır. Ön test ve son testte yer alan her madde ayrı ayrı değerlendirilmiş, analize ait sonuçlar Tablo 6' da sunulmuştur. 
Akademisyenlerin Açık Erişim ve Kurumsal Akademik Arşiv Konusunda Bilgi ve Farkındalık Düzeylerinin Belirlenmesi: Bartın Üniversitesi Uygulama Örneği

Determining the Level of Knowledge and Awareness of Academicians on Open Access and Institutional

Tablo 6

Ön test son test bulgulart

\begin{tabular}{|c|c|c|c|c|c|c|}
\hline & & $\begin{array}{l}\text { nlayıcı } \\
\text { tikler } \\
\text { Mean }\end{array}$ & & $\mathbf{N}$ & $\mathbf{Z}$ & $\begin{array}{l}\text { Asymp. } \\
\text { Sig }\end{array}$ \\
\hline \multirow{3}{*}{ Açık erişimli dergiler bilimsel iletişime katkı sağlar. } & & & Ns & 78 & \multirow{3}{*}{$-0,335$} & \multirow{3}{*}{0,738} \\
\hline & öt & 4,42 & Ps & 82 & & \\
\hline & st & 4,45 & $\mathrm{E}$ & 124 & & \\
\hline \multirow{3}{*}{$\begin{array}{l}\text { Açık erişim ve kurumsal akademik arşivler yazarlara } \\
\text { katkı sağlar. }\end{array}$} & & & Ns & 46 & \multirow{3}{*}{$-7,511$} & \multirow{3}{*}{0,00} \\
\hline & öt & 3,79 & Ps & 151 & & \\
\hline & st & 4,37 & $\mathrm{E}$ & 87 & & \\
\hline \multirow{2}{*}{$\begin{array}{l}\text { Açık erişim ve kurumsal akademik arşivler bilimsel } \\
\text { iletişimin sınırlarını genişletir. }\end{array}$} & öt & 4,06 & $\begin{array}{l}\text { Ns } \\
\text { Ps }\end{array}$ & $\begin{array}{l}64 \\
121\end{array}$ & \multirow[t]{2}{*}{$-4,384$} & \multirow[t]{2}{*}{0,00} \\
\hline & st & 4,36 & $\mathrm{E}$ & 99 & & \\
\hline \multirow{3}{*}{$\begin{array}{l}\text { Açık erişim ve kurumsal akademik arşivlerin } \\
\text { desteklenmesi dergi tekelini azaltacaktır. }\end{array}$} & & & Ns & 68 & \multirow{3}{*}{$-4,771$} & \multirow{3}{*}{0,00} \\
\hline & ot & 3,73 & Ps & 132 & & \\
\hline & st & 4,12 & E & 84 & & \\
\hline \multirow{2}{*}{$\begin{array}{l}\text { Açık erişim ve kurumsal akademik arşivlerin rekabet } \\
\text { ortamını teşvik etmektedir. }\end{array}$} & öt & 3,79 & $\begin{array}{l}\text { Ns } \\
\text { Ps }\end{array}$ & $\begin{array}{l}74 \\
130\end{array}$ & \multirow[t]{2}{*}{$-3,954$} & \multirow[t]{2}{*}{0,00} \\
\hline & st & 4,08 & $\mathrm{E}$ & 80 & & \\
\hline \multirow{2}{*}{$\begin{array}{l}\text { Açık erişim ve kurumsal akademik arşivler } \\
\text { üniversitelere ve kütüphanelere ekonomik anlamda } \\
\text { rahatllk sağlamaktadır. }\end{array}$} & öt & 4,04 & $\begin{array}{l}\text { Ns } \\
\text { Ps }\end{array}$ & 119 & \multirow[t]{2}{*}{$-3,090$} & \multirow[t]{2}{*}{0,02} \\
\hline & st & 4,26 & $\mathrm{E}$ & 92 & & \\
\hline \multirow[t]{2}{*}{$\begin{array}{l}\text { Üniversitenin açık erişim ve kurumsal akademik arşivi } \\
\text { üniversitenin değerini artırmaktadır. }\end{array}$} & öt & 4,11 & $\begin{array}{l}\text { Ns } \\
\text { Ps }\end{array}$ & $\begin{array}{l}78 \\
112\end{array}$ & \multirow[t]{2}{*}{$-2,889$} & \multirow[t]{2}{*}{0,04} \\
\hline & st & 4,31 & E & 94 & & \\
\hline \multirow{3}{*}{$\begin{array}{l}\text { Açık erişim ve kurumsal akademik arşivlerin daha etkin } \\
\text { çalışmasında üniversite kütüphanelerinin rol ve } \\
\text { sorumlulukları bulunmaktadır. }\end{array}$} & öt & 4,26 & Ns & 74 & \multirow{3}{*}{$-1,116$} & \multirow{3}{*}{0,265} \\
\hline & & & Ps & 94 & & \\
\hline & st & 4,33 & E & 116 & & \\
\hline \multirow{3}{*}{$\begin{array}{l}\text { Açık erişim ve kurumsal akademik arşivlerin daha etkin } \\
\text { çalışması için uzman personele gereksinim vardır. }\end{array}$} & & & Ns & 80 & \multirow{3}{*}{$-2,442$} & \multirow{3}{*}{0,015} \\
\hline & öt & 4,03 & Ps & 114 & & \\
\hline & st & 4,21 & E & 90 & & \\
\hline
\end{tabular}

Ön test ve son test kapsamında araştırılan iki madde haricindeki tüm maddelerde akademisyen katılımcıların bilgi ve farkındalıklarının pozitif yönde değişim gösterdiği tespit edilmiştir. Eğitim öncesi ve sonrası katılımcıların düşünceleri arasında istatistiksel olarak 
anlamlı bir fark görülmeyen maddelerden ilki "Açık erişimli dergiler bilimsel iletişime katkı sağlar" diğeri ise "Açık erişim ve kurumsal akademik arşivlerin daha etkin çalışmasında üniversite kütüphanelerinin rol ve sorumlulukları bulunmaktadır” ifadesidir. Her iki madde için de akademisyenlerin ön test ve son test ortalamaları yüksek bulunmakla birlikte verilen eğitimin katılımcıların bu konudaki düşüncelerine pozitif ya da negatif bir yön yaratmadığ görülmektedir. Ancak katılımcılara yönlendirilen diğer maddelere bakıldığında her maddenin ön test-son test puanları arasındaki farkın istatistiksel olarak anlamlı olduğu ve katılımcıların son testteki ortalamalarının yükseldiği ve bununla birlikte üretilen anlamlılık değerlerinin 0,05'ten küçük olduğu $(\mathrm{p}<0,05)$ görülmektedir. Başka bir ifade ile katılımcıların ilgili maddeler için eğitim öncesi ve sonrası düşünceleri arasında anlamlı bir fark olduğu ifade edilebilmektedir. Elde edilen bulgular açık erişim ve kurumsal akademik arşivler temelinde verilen eğitimin katılımcıların bilgi ve farkındalıklarında pozitif yönlü değişim gösterdiğini ortaya koymaktadır. Bununla birlikte "Açık erişim ve kurumsal arşivler yazarlara katkı sağlar", "Açık erişim ve kurumsal akademik arşivler bilimsel iletişimin sınırlarını genişletir" ve "Açık erişim ve kurumsal akademik arşivlerin desteklenmesi dergi tekelini azaltacaktır" ifadeleri pozitif yönlü değişimin daha net izlendiği maddeler olarak dikkat çekmektedir.

\section{Değerlendirme ve Sonuç}

Bu çalışmada Bartın Üniversitesi akademisyenlerinin açık erişim ve kurumsal akademik arşiv konusundaki mevcut bilgi ve farkındalık düzeylerini belirlemek ile birlikte, akademisyenlere açık erişim ve kurumsal akademik arşiv konusunda eğitim verildikten sonra akademisyenlerin bu konudaki bilgi ve farkındalık düzeylerinde yaşanan değişimin incelenmesi amaçlanmıştır. Katılımcı akademisyenler tarafından eğitimden önce doldurulan anketin sonuçları değerlendirildiğinde akademisyenlerin büyük çoğunluğunun akademik sosyal ağları aktif olarak kullanmasına rağmen, üniversitenin kurumsal akademik arşivinden haberdar olmadığ1 veya daha önce hiç yayın yüklemediği tespit edilmiştir. Kurumsal akademik arşive yayın yükleyen akademisyenlerin tüm katılımcıların sadece $\% 6$ 'sı olduğu belirlenmiştir. Bu oran oldukça az olmakla birlikte, ilgili tarihlerde Bartın Üniversitesi Kurumsal Akademik Arşivine tezler haricinde yüklenen kayıt sayısı dikkate alındığında, arşive kayıtlı yayın sayısının, tespit edilen bu oranın doğruluğunu destekler nitelikte olduğu anlaşılmaktadır. Akademisyenler kurumsal akademik arşivi kullanmamış ve daha önce yayın yüklememiş olma nedenlerinin başında, üniversitenin kurumsal akademik arşivi ile ilgili bilgi ve eğitim eksikliğine bağlı olarak, nasıl yayın yükleyeceklerini bilmiyor olmalarını temel gerekçe olarak sundukları görülmektedir. Bu iki noktadan hareketle akademisyenlerin açık erişim ve kurumsal akademik arşiv konusunda özellikle arşive yayın yükleme aşamasında teknik destek, eğitim ve bilgilendirme eksiklikleri yaşadıkları net olarak anlaşılmaktadır. Çalışmadan elde edilen bulgular, akademisyenlerin büyük bir kısmının açık erişim ve kurumsal akademik arşiv temelinde daha önce hiçbir eğitim, seminer veya benzeri bir bilgilendirme toplantısına katılmadığını buna bağlı olarak açık erişim ve kurumsal akademik arşivler konusunda eğitim ve teknik desteğe gereksinim duyduklarını ortaya koymaktadır.

Akademisyen katılımcılara eğitim verildikten sonra görüşlerine tekrar başvurulmuş ve eğitimden sonra akademisyenlerin büyük çoğunluğunun üniversitenin kurumsal akademik arşivine yayın yükleyebilecek kadar teknik bilgiye sahip oldukları ve bu eğitimden sonra telif sorunu bulunmayan yayınlarını Bartın Üniversitesi Kurumsal Akademik Arşivi’ne yüklemeyi 
Akademisyenlerin Açık Erişim ve Kurumsal Akademik Arşiv Konusunda Bilgi ve Farkındalık Düzeylerinin Belirlenmesi: Bartın Üniversitesi Uygulama Örneği

Determining the Level of Knowledge and Awareness of Academicians on Open Access and Institutional Repositories: An Example of Bartın University

düşündükleri sonucu ile karşılaşılmıştır. Nitekim elde edilen bu sonuç eğitim sonrasında kurumsal akademik arşivdeki yayın sayısı artışını açıklamaktadır. Üniversite kurumsal akademik arşivinin kurulmasından, eğitim başlangıcına kadar yüklenen yayın sayısı ile eğitim sonrasında yüklenen yayın sayıları karşılaştırıldığında bu durum net olarak izlenmektedir. Yapılan eğitim toplantıları sonrasında -15 Mayıs 2019 tarihi ile 16 Kasım 2019 tarihleri arasında- Bartın Üniversitesi Kurumsal Akademik Arşiv Sistemine girilen kayıt sayısının 412'den 5.556'ya yükseldiği görülmektedir. Bir diğer ifade ile Bartın Üniversitesi Kurumsal Akademik Arşivine girilen veri sayısında eğitim tamamlandıktan sonra dikkat çekici oranda ilerleme kaydedilmiştir.

Açık erişim ve kurumsal akademik arşivler temelinde akademisyenlere verilen eğitimden önce ve sonra katılımcıların bilgi ve farkındalıkları değerlendirildiğinde; eğitim sonrasında akademisyenlerin bilgi ve farkındalıklarında olumlu anlamda bir değişim olduğu gözlemlenmiştir. Verilen eğitimin; bilimsel iletişimin artması, yazarlara ve üniversiteye katkı sağlaması, dergi tekelini azaltması, yazarlar arası rekabet ortamını teşvik etmesi, kurumlara bilimsel yayınlara ulaşmada ekonomik rahatlık sağlaması, kurumsal akademik arşivlerin uzman personel tarafından yönetilmesi konularında akademisyenlerin mevcut bilgi ve farkındalıklarında pozitif anlamda değişim yarattı̆̆ı gözlemlenmiştir. Akademisyenlerin mevcut bilgi ve farkındalıklarında değişim göstermeyen iki madde vardır. Bu maddelerden ilki açık erişimli dergilerin bilimsel iletişime sağladığı katkı diğeri ise açık erişim ve kurumsal akademik arşivlerin daha etkin çalışmasında üniversite kütüphanelerinin rol ve sorumlulukları ile ilgilidir. Her iki ifadeye de verilen ön test yanıtlarının oldukça yüksek olması, eğitime katılan akademisyenlerin bu konularda eğitim öncesinde de bilgi ve farkındalıklarının yüksek olduğunu göstermektedir. $\mathrm{Bu}$ nedenle akademisyenlerin son testte verdikleri yanitlarda anlamlı bir farklılık ortaya çıkmamıştır.

Çalışmanın bir diğer önemli sonucu da Türkiye'de açık erişim ve kurumsal açık arşiv konularında yapılan çalışmalara yeni bir boyut kazandırmasıdır. Çalışma kapsamında yapılan eğitim semineri ve akademisyenlerin eğitim öncesi ve sonrasında bu konudaki düşüncelerinde yaşanan değişimin incelenmesi amacıyla kullanılan "tek örneklem ön test son test deseni" Türkiye'de bu konu ile ilgili bir çalışmada ilk kez kullanılmıştır. Açık erişim ve kurumsal açık arşiv konularında yapılan çalışmalarda sık sık ifade edilen "açık erişim ve kurumsal akademik arşiv konusunda eğitimler verilmeli” önerisi uygulanmış ve sonuçları da somut bir şekilde ortaya çıkarılmıştır. Bu yönüyle çalışma gelecekte bu konuda yapılacak çalışmalara farklı bir bakış açısı kazandıracaktır.

$\mathrm{Bu}$ araştırmadan elde edilen bulgular ve sonuçlara dayanılarak aşağıdaki öneriler geliştirilmiştir:

- Bartın Üniversitesi Kütüphane ve Dokümantasyon Daire Başkanlığının koordinasyonuyla, Üniversitenin akademik birimlerinde açık erişim ve kurumsal akademik arşivler konusunda belirli aralıklarla sürdürülebilir etkinlikler yapılmalıdır. 
- Üniversite kütüphanesi, bilgilendirme ve farkındalık yaratma konularında önemli rol ve sorumluluklarını büyük ölçekte kütüphaneciler aracılığıyla gerçekleştirmektedir. $\mathrm{Bu}$ nedenle üniversite kütüphanesinde görev yapan kütüphanecilerin açık erişim konusundaki sempozyum, kongre, panel, seminer vb. etkinliklere katılımları desteklenmelidir.

- Yükseköğretim Kurulu tarafından akademisyenlerin üniversitelerinin kurumsal akademik arşiv sistemini aktif olarak kullanmalarını sağlamak amacıyla bazı kararlar aldığ ve bu doğrultuda üniversitelere öneriler sunduğu bilinmektedir. Bununla birlikte uygulama noktasında hala eksikliklerin var olduğu anlaşılmaktadır. Bu kapsamda üniversite yönetimlerinin kurumsal yükseltmelerde ve teşviklerde akademik çalışmaların kurumsal akademik arşiv sistemine yüklenmesi şartını titizlikle uygulamaları ya da ödüllendirme sistemi gibi farklı motivasyon unsurlarından yararlanmaları yararlı olacaktır.

- 2019-2020 bahar döneminde dünyada ve Türkiye'de yaşanılan Covid-19 pandemisi sebebiyle üniversiteler uzaktan eğitim sistemine geçmiştir. Bununla birlikte "kurumsal dijital akademi” içeriğinin ne denli önemli olduğu tecrübe edilmiştir. Türkiye'de de Yükseköğretim Kurulu tarafından YÖK Dersleri Platformu adı altında ders kaynaklarının dijital ortama aktarıldığı bir proje gerçekleştirilmiştir. Üniversiteler de derslerini, ders içeriklerini, bilimsel faaliyetlerini ve projelerini dijital ortama aktararak kurumsal açık arşivlerine yüklemeli ve bu sürece katkı sağlamalıdır.

Bilimsel iletişimin sınırlarını geliştiren önemli bir olgu olan açık erişim, üniversiteler tarafından titizlikle planlanması ve yürütülmesi gereken bir süreçtir. Üniversitelerde açık erişim konusunda yapılan çalışmaların başarı ya da başarısızlığında üniversite kütüphanelerinin önemli etkisi bulunmaktadır. Aktif ve sürekliliği olan bir açık erişim ve kurumsal akademik arşivin oluşturulması ve yürütülmesinde üniversite kütüphanelerine ve kütüphanecilerine büyük sorumluluklar düşmektedir. Bununla birlikte bu sorumluluk sadece üniversite kütüphanelerine yüklenmemelidir. Üniversite yönetimleri başta olmak üzere, üniversitelerin tüm fakülteleri, enstitüleri, meslek yüksekokulları ve araştırma merkezlerinin bu süreçteki desteği ve iş birliği son derece önemlidir. 
Akademisyenlerin Açık Erişim ve Kurumsal Akademik Arşiv Konusunda Bilgi ve Farkındalık Düzeylerinin Belirlenmesi: Bartın Üniversitesi Uygulama Örneği

Determining the Level of Knowledge and Awareness of Academicians on Open Access and Institutional Repositories: An Example of Bartin University

\section{Kaynakça}

Açık Erişim Farkındalık ve Memnuniyet Anketi Sonuç Raporu. Erişim adresi: https://ulakbim.tubitak.gov.tr/sites/images/Ulakbim/acik_erisim_anket_raporu_aralik_2015.pdf

Afzali, M. (2009). Türkiye'de açık erişim, kurumsal arşivler ve akademik kütüphaneler. Yayımlanmamış doktora tezi. Hacettepe Üniversitesi, Ankara.

Afzali, M. ve Tonta Y. (2010). Türkiye'deki kurumsal arşivlerin web analizi. 2. Uluslararası Değişen Dünyada Bilgi Yönetimi Sempozyumu, 22-24 Ekim 2010 Hacettepe Üniversitesi, Ankara, Bildiriler Kitabl içinde (s.155-163). Erişim adresi: http://bilgiyonetimi.net/by2010/bildiriler/afzali.pdf

Akın, S. (2018). Türkiye'de akademilerde açık erişim ve bir açık erişim modeli önerisi. Yayımlanmamış yüksek lisans tezi Çankırı Karatekin Üniversitesi, Sosyal Bilimler Enstitüsü, Çankırı.

Al, U. ve Tonta, Y. (2014). Açık Erişim politikalarının geliştirilmesi ve PASTEUR4OA Projesi. Türk $\begin{array}{lllll}\text { Kütüphaneciliği, } & 28 & (3), & 433-436 . & \text { Erişim }\end{array}$ http://www.tk.org.tr/index.php/TK/article/view/2455/2438

Alaca, E., Büyükçolpan, T. ve Kanık, L. (2019). Bilimsel bilginin erişiminde ve paylaşımında kurumsal açık arşiv yaklaşımı: Ankara Yıldırım Beyazıt Üniversitesi örneği. Bilgi Dünyası, 20(2), 1-39. doi: 10.15612/BD.2019.736

Alav, O. (2018). Açık bilim: açık erişim Türkiye \& Türkiye'deki kurumsal açık erişim arşiv organizasyonlarının yönetişim uygulamalarının değerlendirilmesi. İstanbul, Hiperyayın.

Alav, O. (2019). Türkiye'deki kurumsal açık erişim organizasyonlarının yönetişim uygulamalarının değerlendirilmesi üzerine bir araştırma. Mehmet Akif Ersoy Üniversitesi Sosyal Bilimler Enstitüsü Dergisi, 11(29), 503-529. doi: 10.20875/makusobed.595502

Altunışık, R., Coşkun, R., Bayraktaroğlu, S. ve Yıldırım, E. (2012). Sosyal Bilimlerde Araştırma Yöntemleri SPSS Uygulamalı (Geliştirilmiş 7. Baskı). İstanbul: Avcı Ofset.

Bailey, C. W. (2006). What is Open Access? Erişim adresi: http://digitalscholarship.org/cwb/WhatIsOA.htm

Bartlett, J. E., Körtlik, J. W., \& Higgins, C. C. (2001). Organizational research: Determining appropriate sample size in survey research. Information Technology, Learning, and Performance Journal, 19(1), 43-50.

Berlin Declaration on Open Access to Knowledge in the Sciences and Humanities (October 22, 2003). Erişim adresi: https://openaccess.mpg.de/Berlin-Declaration

Bethesda Statement on Open Access Publishing (June 20, 2003). Erişim adresi: https://www.researchgate.net/deref/https $\% 3 \mathrm{~A} \% 2 \mathrm{~F} \% 2 \mathrm{Fdash}$.harvard.edu\%2Fbitstream\%2Fhandl e\%2F1\%2F4725199\%2Fsuber_bethesda.htm 
Çelik, S. ve Çelik, R. (2019). Sürdürülebilir bir kurumsal akademik arşiv yönetimi: Doğuş Üniversitesi Akademik Arşiv Sistemi deneyimi. Yükseköğretim Dergisi, 9(1), 91-102. doi: 10.2399/yod.18.020

Çelik, S., Gürdal, G., Keten, B., Türkfidanı, A. ve Kutlutürk, L. (2013). Açık erişim ve DSpace kurumsal arşiv yazılımı. Erişim adresi: http://ab.org.tr/ab13/bildiri/250.pdf

Dilek-Kayaoğlu, H. (2006). Açık erişim kavramı ve gelişmekte olan bir ülke olarak Türkiye için anlam1. Türk Kütüphaneciliği, 20 (1), 29-60. Erişim adresi: http://www.tk.org.tr/index.php/TK/article/view/79/78

Ennals, R. (2003). Yeni Binyılın Üniversitesinin Yeni Paradigması olarak Eylem-Araştırma. O.N. Babüroğlu ve Z. Dicleli (Yay. Haz.). Eğitimin Geleceği: Üniversitelerin ve Eğitimin Değişen Paradigması içinde (s. 91-104). İstanbul: Sabancı Üniversitesi.

Eroğlu, A. E. (2013). Neden açık erişim?. 2. Ulusal Açık Erişim Çalıştayı içinde (s. 1-22). Erişim adresi:

http://library.iyte.edu.tr/dosya/2UlusalAcikEriismIYTE21ekim2013/Ahmet\%20EROGLU.pdf

Ertürk, K. L. ve Küçük, M. E. (2010). Kurumsal açık arşivlerin etkin kullanımı: Türkiye'deki bilimsel elektronik yayıncıların görüşleri. Bilgi Dünyası, 11 (1), 122-139.

Gürdal, G., Türkfidanı, A., Kutlutürk, L., Çelik, S. ve Keten, B. (2012). Araştırma kurumları için OpenAIRE kllavuzu. Erişim adresi: https://openaccess.dogus.edu.tr/xmlui/bitstream/handle/11376/127/TK_OpenAIRE_kilavuzu.pd $\mathrm{f}$ ? sequence $=1$ \&isAllowed $=\mathrm{y}$

Köse, G. ve Küçük, M. E. (2010). Açık erişim farkındalığı: Başkent Üniversitesi. S. Kurbanoğlu, Y. Tonta, U. Al, P. Lepon Erdoğan, N. Özenç Uçak (Yay. Haz.) Bilgi Yönetiminde Teknolojik Yakınsama ve Sosyal Ağlar, 2. Uluslararası Değişen Dünyada Bilgi Yönetimi Sempozyumu, 2224 Eylül 2010, Ankara, Türkiye, Bildiriler içinde (s.264-270). Ankara: Hacettepe Üniversitesi Bilgi ve Belge Yönetimi Bölümü. Erişim adresi: http://www.openaccess.hacettepe.edu.tr:8080/xmlui/bitstream/handle/11655/11539/bildiri_kitap 2010.pdf? sequence $=1 \#$ page $=280$

MedOANet (2012). MedOANet (Mediterranean Open Access Networks). Erişim adresi: http://www.medoanet.eu/home

MedOANet (2013). Araştırma yapan ve destekleyen kurumlar için MedOANet Açık Erişim Politikaları Uygulama İlkeleri. Erişim adresi: http://medoanet.eu/sites/www.medoanet.eu/files/documents/MEDOANET2013_GUIDLine_dp_ TR_ws.pdf

Odabaşoğlu, A. (2017). Bilim insanlarının açık erişimli dergiler konusundaki bilinç ve tutumları: Başkent Üniversitesi örneği (Yayımlanmamış yüksek lisans tezi). Ankara Üniversitesi, Ankara.

OpenAIRE (2013). OpenAIRE open access infrastructure for research in europe. Erişim adresi: https://www.openaire.eu/openaire-factsheet-pdf

PASTEUR4OA (2015). PASTEUR4OA: açık erişim politika etkinliği: araştırma kurumları için kısa bilgilendirme. Erişim adresi: http://www.pasteur4oa.eu/sites/pasteur4oa/files/resource/openaccess-policy-effectiveness_a-briefing-paper-for-research-institutions_tr.pdf 
Akademisyenlerin Açık Erişim ve Kurumsal Akademik Arşiv Konusunda Bilgi ve Farkındalık Düzeylerinin Belirlenmesi: Bartın Üniversitesi Uygulama Örneği

Determining the Level of Knowledge and Awareness of Academicians on Open Access and Institutional Repositories: An Example of Bartın University

PASTEUR4OA (2016). PASTEUR4OA Final Conference. Erişim adresi: http://www.pasteur4oa.eu/final-conference\#.X18HvmgzbIXv

PASTEUR4OA (2020). Erişim adresi: http://www.pasteur4oa.eu/home

Tonta, Y. (2007). Açık erişim ve tıpta bilimsel iletişimin geleceği. Bilimsel Yayınlar Kitabı içinde. Ankara, Klinik Araştırmalar Derneği. Erişim adresi: http://openaccess.hacettepe.edu.tr:8080/xmlui/handle/11655/11802

Yang, Z. Y. (Lan) ., \& Li, Y. (2015). University faculty awareness and attitudes towards open access publishing and the institutional repository: a case study. Journal of Librarianship and Scholarly Communication, 3(1), doi:10.7710/2162-3309.1210

\section{Summary}

Institutional repository systems are platforms where intellectual works which, produced by universities and research centers, are archived electronically and freely accessible to everyone. In order to provide a sustainable institutional repository system in universities, repository must be constantly fed by faculty members. It is thought to be important to have high level of knowledge and awareness of faculty members about open access and institutional repositories to provide this continuity.

Since 2012, Turkey is seen as important steps thrown about Open Access and institutional repositories. TheCouncil of Higher Education (CoHE) sent an official letter to universities in 2014 regarding the institutional archives of the universities. In this official article, universities were asked to take concrete steps to create their institutional repositories and improve their archive policies. The last months of 2018 and 2019 was an important milestone in the development of the subject of open access and institutional repositories in Turkey. In February 2019, an other official letter was sent to the universities by CoHE on open access and institutional repositories. With this article, CoHE has collected the procedures to be done for open access and institutional repositories in 14 articles, and with this article, it has been stated that the institutional repositories of the universities will be followed statistically in 6-month periods. Most importantly, in this article, the emphasis was made on the necessity of holding meetings to ensure the awareness of academics to provide the sustainability of repositories.

In this study, a training, which was about open access and institutional repository, was held at Bartın University, in order to increase the level of knowledge and awareness of academicians working and it was aimed to examine the changes experienced in academicians' opinions before and after the training. In this context, quantitative research methods were used and single sample pre-test post-test pattern was used. SPSS (Statistical Package for Social Sciences) 22.0 package program was used in the analysis of the data. As a result of the study, it was determined that faculty members needed training on open access and institutional repositories for effective usage of this repositories. In addition, after the training, it was concluded that there was a statistically significant positive change in the knowledge and 
awareness of faculty members on open access and institutional repositories. Within the scope of the study, it was determined that Bartın University Institutional Repository was used by very few academicians. It is seen that academicians do not use the institutional repository and have not uploaded publications before, as the main reason that they do not know how to upload the publication due to the lack of knowledge and technical education about the university's institutional repository. When the reason for the fact that the Bartın University Institutional Repository has not been used in the desired efficiency so far, it is seen that the lack of information and education developed due to lack of communication was given as a high rate of response. Based on these two points, it is clearly understood that academicians are lacking technical support, training and information about open access and institutional repositories, especially in the process of uploading document to the repository. Moreover, the data obtained from the surveys reveal that the vast majority of academicians have not previously attended any training, seminars or similar information meetings on the basis of open access and institutional repositories, but academicians need training, technical support and information on this issue. It is undoubted that university libraries have a great role and importance in the presence of an active and continuous open access and institutional repository. However, the support and cooperation of the Faculties, Institutes, Vocational Schools and Research Centers, especially the Rectorate, in this process is extremely important. 